\title{
Mars Surface Mobility Leading to Sustainable Exploration
}

\author{
Diane L. Linne ${ }^{1}$, Stephen J. Barsi ${ }^{2}$, Waldy K Sjauw En $\mathrm{Wa}^{3}$, and Geoffrey A. Landis ${ }^{4}$ \\ NASA Glenn Research Center, Cleveland, OH 44133
}

\begin{abstract}
A Mars rocket-propelled hopper concept was evaluated for feasibility through analysis and experiments. The approach set forth in this paper is to combine the use of in-situ resources in a new Mars mobility concept that will greatly enhance the science return while providing the first opportunity towards reducing the risk of incorporating ISRU into the critical path for the highly coveted, but currently unaffordable, sample return mission. Experimental tests were performed on a high-pressure, self-throttling gaseous oxygen/methane propulsion system to simulate a two-burn-with-coast hop profile. Analysis of the trajectory, production plant requirements, and vehicle mass indicates that a small hopper vehicle could hop $2 \mathrm{~km}$ every 30 days with an initial mass of less than $60 \mathrm{~kg}$. A larger vehicle can hop $15 \mathrm{~km}$ every 30 to 60 days with an initial mass of 300 to $430 \mathrm{~kg}$.
\end{abstract}

\section{Nomenclature}

$\begin{array}{ll}\mathrm{A} & =\text { area } \\ \mathrm{Cd} & =\text { discharge coefficient } \\ \mathrm{C}_{\mathrm{p}} & =\text { specific heat capacity } \\ \mathrm{D} & =\text { diameter } \\ \mathrm{g}_{\mathrm{c}} & =\text { conversion factor } \\ \mathrm{h} & =\text { heat transfer coefficient } \\ \mathrm{M} & =\text { Mach number } \\ \mathrm{m} & =\text { mass } \\ \mathrm{mdot} & =\text { mass flow rate } \\ \mathrm{P} & =\text { pressure } \\ \mathrm{Pr} & =\text { Prandtl number } \\ \mathrm{q} ” & =\text { heat flux } \\ \mathrm{R} & =\text { gas constant } \\ \mathrm{r} & =\text { radius of curvature } \\ \mathrm{T} & =\text { temperature }\end{array}$

$\begin{array}{ll}\frac{\text { Subscripts }}{\mathrm{o}} & =\text { stagnation } \\ \mathrm{rec} & =\text { recovery } \\ \mathrm{t} & =\text { throat } \\ \mathrm{u} & =\text { upstream }\end{array}$

$\underline{\text { Greek }}$

$\pi \quad=$ flow coefficient

$\gamma=$ ratio of specific heats

$\mu \quad=$ dynamic viscosity

$\sigma \quad=$ heat transfer coefficient correction factor

\section{Introduction}

SURFACE exploration of Mars has so far been conducted with rovers that are limited by terrain and soil stability challenges. At the same time, analysis for sample return missions is mired in the traditional approach of bringing all the return propellant from Earth, resulting in a recent Mars sample return plan that calls for three launches over 10 years. ${ }^{1}$ A Mars mobility concept where the vehicle performs a series of suborbital ballistic hops can cover greater distances than a rover and can fly over difficult terrain un-passable by a surface vehicle. If this vehicle also carries with it a propellant production plant that can refill the tanks from in-situ resources at every stop, then it can serve the dual purpose of performing exciting Mars scientific exploration while providing critical demonstrations of a gamechanging exploration concept that will lead to sustainable and affordable exploration of our closest neighbor.

Earlier work on the Mars hopper concept focused on dissociating the carbon dioxide in the Mars atmosphere and storing the oxygen and carbon monoxide for later use in a rocket engine to perform a suborbital ballistic hop to a new exploration site. ${ }^{2}$ The advantage of this propellant combination is that it can be made entirely from the

\footnotetext{
${ }^{1}$ Senior Research Engineer, Power and In-Space Propulsion Division, MS 301-3, AIAA Associate Fellow.

${ }^{2}$ Aerospace Engineer, Power and In-Space Propulsion Division, MS 301-3, AIAA Member.

${ }^{3}$ Aerospace Engineer, Mission Design and Analysis Branch, MS 105-3.

${ }^{4}$ Senior Research Engineer, Power and In-Space Propulsion Division, MS 302-1, AIAA Associate Fellow.
} 
atmosphere, which is relatively easy to acquire and process compared to digging and extracting resources from the regolith. However, the carbon monoxide fuel provides a fairly low specific impulse performance, and its extensibility to more demanding missions such as sample return or human ascent is questionable.

In the ten years since the oxygen/carbon monoxide hopper concept was first developed, new orbital and surface observations have revealed that the surface of Mars is not a completely arid environment, with significantly more water resource and in a wider distribution than was once believed. ${ }^{3,4}$ These discoveries have reignited the concept of making methane on Mars for propulsion with oxygen. Previously, the biggest drawback to the methane option was the need to bring hydrogen from Earth, which is difficult to store and transport due to its low density and liquefaction temperature. This paper presents the results of an analytic effort to design a Mars hopper vehicle powered by methane and oxygen in-situ propellants, including detailed estimates of the mass of the propulsion system, production plant, and power system. The potential range of the hopper is also presented for two different size vehicles. Finally, experimental test results are presented demonstrating the effectiveness of a low complexity gas-gas propulsion system suitable for a small hopper explorer.

\section{Mars Hopper Concept and Trajectory}

Sizing a Mars hopper that uses in-situ propellants is an iterative process, where the mass and volume of the production plant and the size of the propellant tanks is dependent on the amount of propellant required for each hop. The propellant requirement can be determined through trajectory analysis and optimization, but this requires either an initial mass or dry mass for the vehicle, which includes the mass of the production plant and propulsion system. To begin the analysis, an initial mass for a small, short-range hopper (e.g., $<5 \mathrm{~km}$ ) was selected and trajectory parametrics were performed while varying engine thrust, downrange distance, and the method for controlling the descent burn thrust decay. The propellant requirements resulting from the initial trajectory analysis were used to size the propulsion system, production plant, and hopper vehicle. With this higher fidelity estimate on vehicle mass, the trajectory analysis was then repeated for several values of initial vehicle mass in the range likely for this short-range hopper. Finally, another

Table I. Trajectory ground rules and assumptions.

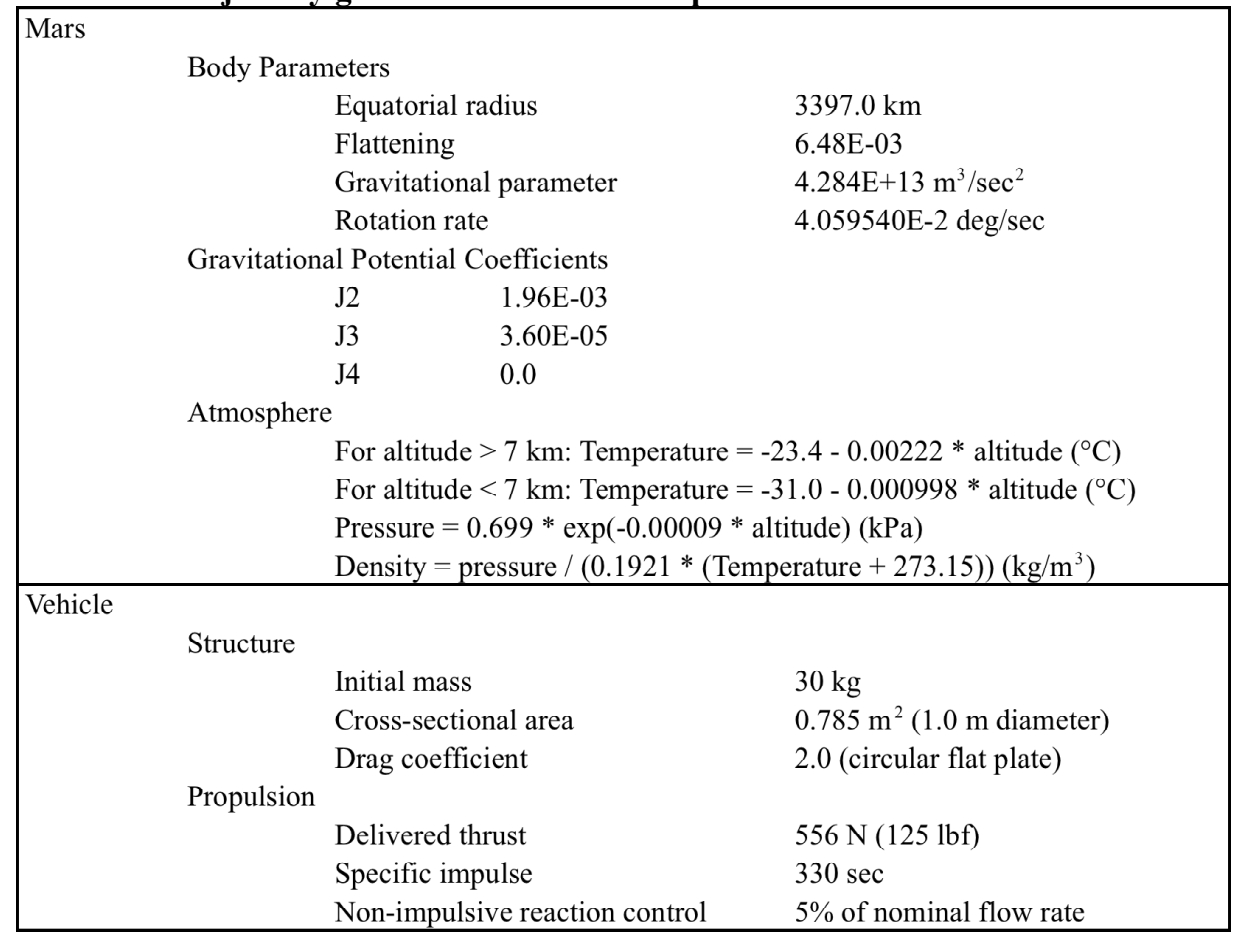
round of trajectories were run with a much larger initial mass for a vehicle capable of hop distances in the range of 10 to $20 \mathrm{~km}$. This section describes the trajectory analysis methods, assumptions, and results.

Trajectory analysis for the Mars Hopper was performed using the Optimal Trajectories by Implicit Simulation (OTIS) program, version $4 .{ }^{5}$ OTIS is widely used across the U.S. aerospace industry for a range of applications from conceptual mission and vehicle design work to near-term launch independent verification and validation. The overall trajectory profile for the Mars Hopper assumes a planar flight in order to reduce the propellant requirement to accomplish the mission. The objective was to minimize the propellant used. Table I shows the assumptions and ground rules used in the trajectory model of the Hopper vehicle. The overall mission profile is listed below. 
- Vertical take-off followed by a pitch-over during which flight path angle rate is not to exceed $-0.175 \mathrm{rad} / \mathrm{sec}$ (approximately -10 deg/sec). Constant maximum thrust. Alpha pitch-over profile can be up to 2 nd order in shape.

- Ballistic coast with a non-impulsive flow at 5 percent of the nominal maximum burn flow rate to account for attitude control maneuver's propellant usage.

- Rev1 profile: Propulsive landing during which the thrust is allowed to throttle down to 10 percent of maximum thrust, if needed. The throttle profile is an optimized spline subject to a $(-0.1$ to 0$)(1 / \mathrm{sec})$ rate limit down to $10 \mathrm{~m}$ altitude and vertical position, followed by a $(-1.0$ to 0$)(1 / \mathrm{sec})$ rate limit during the final $10 \mathrm{~m}$ vertical descent. Final "touchdown" throttle setting is derived from requiring the final thrust-to-weight $(\mathrm{t} / \mathrm{w})$ ratio to be 1 Mars $g$.

- Rev2 profile: Propulsive landing during which the thrust is allowed to throttle down to $10 \%$ of maximum thrust, if needed. The throttle profile is such that at the beginning of the descent burn, an optimized burn time at the maximum thrust is allowed to enable the descent burn to achieve the needed amount of impulse and to allow the start of the decay to be part of the optimization process. Following this optimized period of maximum thrust, a $3^{\text {rd }}$ order decay-only throttle profile is prescribed. Table II shows the provided and derived coefficients for the $3^{\text {rd }}$ order decay profile that were derived from predictions of the pressure decay in the run tank that are discussed in section III. The $3^{\text {rd }}$ order decay profile is used for the remainder of the descent burn; this includes the pitch-up down to $10 \mathrm{~m}$ altitude and vertical position, followed by the final 10 $\mathrm{m}$ vertical descent. Final "touchdown" throttle setting is derived from limiting the final thrust-to-weight $(\mathrm{t} / \mathrm{w})$ ratio to 1 Mars $\mathrm{g}$.

- Landing Alpha pitch-up profile can be up to $3^{\text {rd }}$ order in shape.

- Vehicle ends in a vertical position.

Figure 1 shows a comparison of the thrust profiles for the Rev1 and Rev2 Mars Hopper profiles. As shown, the burn 1 profile is the same (maximum thrust only). The burn 2 profiles, however, show the difference between the optimized spline and $3^{\text {rd }}$ order thrust decay models, including the optimized period of maximum thrust for the Rev2 profile prior to commencing the decay portion of the burn.

Table II. Coefficients of specified descent burn $3^{\text {rd }}$ order decay throttle profile.

throttle ratio $=\mathrm{C} 0+\mathrm{C} 1 * \mathrm{t}+\mathrm{C} 2{ }^{*} \mathrm{t}^{\wedge} 2+\mathrm{C} 3 * \mathrm{t}^{\wedge} 3$ (where $\mathrm{t}=$ time in sec)

\begin{tabular}{|l|c|c|c|c|}
\hline & $\mathrm{C} 0$ & $\mathrm{C} 1$ & $\mathrm{C} 2$ & $\mathrm{C} 3$ \\
\hline $\mathrm{CH} 4$ & 1.0071 & -0.3097 & 0.0477 & -0.0031 \\
$\mathrm{O} 2$ & 0.9969 & -0.2938 & 0.0442 & -0.0029 \\
\hline & & & & \\
\hline Avg & 1.0020 & -0.3018 & 0.0460 & -0.0030 \\
\hline & & & & \\
\hline Employed in rev2 & 1.0000 & -0.3018 & 0.0460 & -0.0030 \\
\hline
\end{tabular}

Note: $\mathrm{C} 0$ capped at 1.0000 to avoid having more than the maximum possible thrust

\section{A. Initial Trajectory Analysis}

Preliminary trajectory analysis assumed an initial wet vehicle mass of $30 \mathrm{~kg}$. Two thrust levels, $445 \mathrm{~N}$ (100 lbf) and $556 \mathrm{~N}$ (125 lbf), were considered. The initial analysis consisted of a hop distance trade examining distances from 0.5 to $5 \mathrm{~km}$ and gives an indication of the impact of the hop distance requirement and also an early indication of the thrust level impact. The propellant consumption varies modestly in going from a hop distance of $0.5 \mathrm{~km}$ to $5 \mathrm{~km}$; a variation of approximately $1.75 \mathrm{~kg}$. Figure 2 shows the trajectory profile (altitude vs hop distance) for the hop distance trade, and Fig. 3 shows the impact on propellant consumption. The impact of the higher thrust level is an increase in propellant consumption

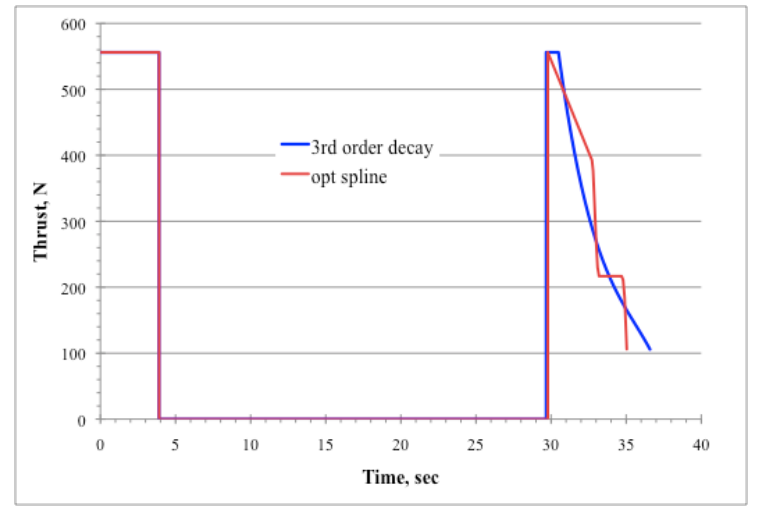

Figure 1. Comparison of Mars Hopper thrust profiles; optimized spline (Rev1) and $3^{\text {rd }}$ order decay (Rev2). 
(approximately 11.8 percent for a $0.5 \mathrm{~km}$ hop and 7.2 percent for a $5 \mathrm{~km}$ hop). However, the higher thrust level enables the hopper to achieve the required propulsive impulse with a shorter burn time that results in cooler engine wall temperatures. Following these preliminary runs, a more detailed thrust trade was examined.

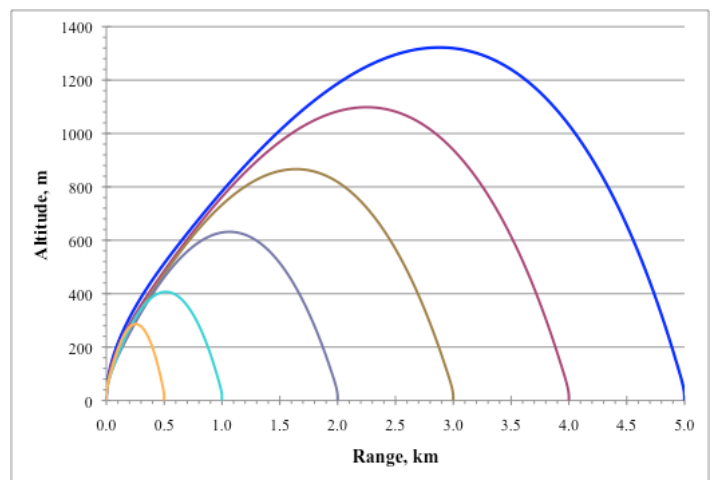

Figure 2. Vehicle altitude vs hop distance profiles (Rev1 descent thrust profile).

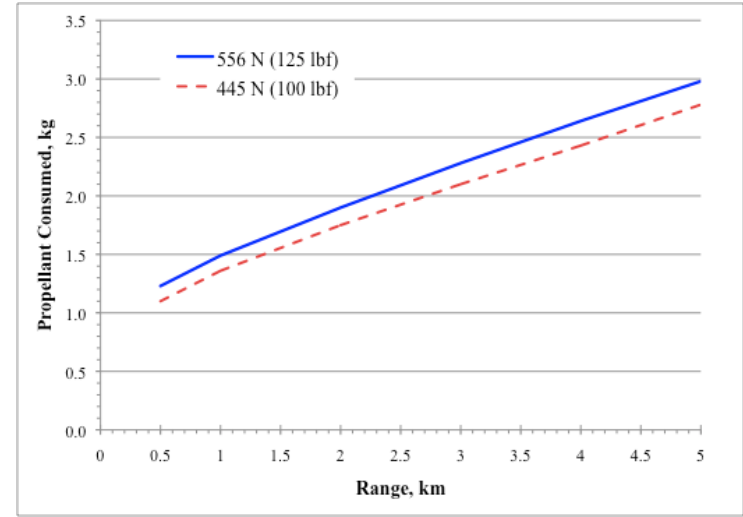

Figure 3. Vehicle propellant consumed vs hop distance for two different thrust levels (Rev1 descent thrust profile).

\section{B. Variation in Thrust}

The Rev1 Mars Hopper model was used to analyze the impact of the maximum thrust level on the hopper trajectory and performance. The range of maximum thrust levels was from $556 \mathrm{~N}$ to $328 \mathrm{~N}$ (125 lbf to $73.75 \mathrm{lbf}$ ). The hop distance was fixed at $5 \mathrm{~km}$, which was chosen as a 'stressing' case.

Figure 4 shows how the flight profile changes with maximum thrust level and Fig. 5 shows the propellant used as a function of the maximum thrust level. As the maximum thrust level decreases, the burn lengths increase because lower thrust levels require longer burn times to achieve the required impulse. The longer burn times eventually outweigh the lower propellant flow rates (lower thrust at the same specific impulse), resulting in higher propellant consumption. Lowering thrust level also results in lower peak altitudes and shorter coast times. The observed trend shows that decreasing thrust levels from $556 \mathrm{~N}$ to approximately $362 \mathrm{~N}(81 \mathrm{lbf})$ results in optimized hop trajectories in the same family of solutions where the vehicle coasts through a peak altitude and begins 'falling' for some time

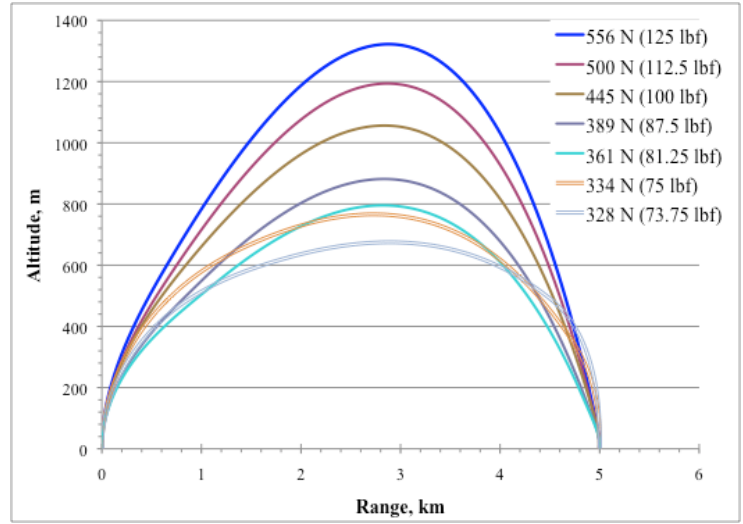

Figure 4. Vehicle thrust trade; altitude and hop distance (Rev1 descent thrust profile).

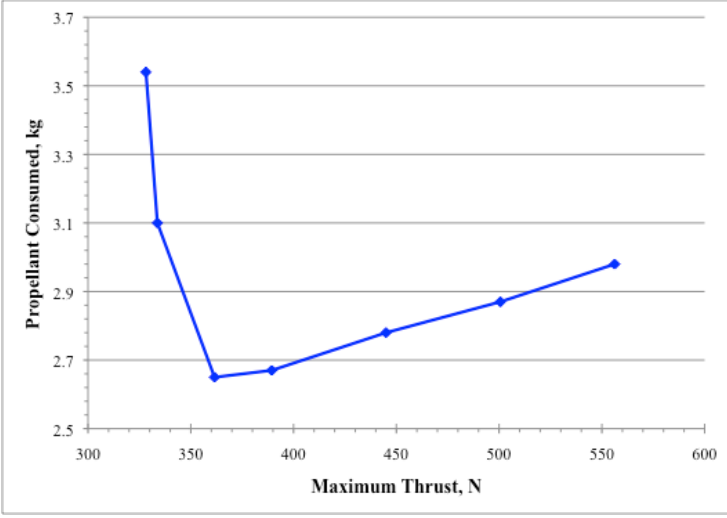

Figure 5. Vehicle thrust and propellant-usage trade (Rev1 descent thrust profile).

before the engines are reignited for a controlled landing. Below this thrust level the hopper trajectory is from a different family of solutions requiring a more aggressive pitch-over profile during burn 1 in order to get further downrange using the lower thrust level. This results in a more "depressed" trajectory, as evidenced by the lower peak altitude (Fig. 4) and increasingly higher apex velocities during the coast (middle portion of Fig. 6). As the maximum thrust level is lowered further, the landing (second) burn needs to start earlier resulting in ever-shorter coast times. In fact, Fig. 6 shows that for the $328 \mathrm{~N}(73.75 \mathrm{lbf})$ thrust case the hopper does not even reach the apex of the ballistic coast when the second burn commences. For cases with the maximum thrust below $362 \mathrm{~N}$, a 
combination of factors also lead to significantly longer second burns. The hopper commences the second burn at a lower altitude while moving faster and at a shorter downrange distance. As a result, the second burn needs to cover increasingly more of the down range distance to achieve the required hop distance. The hopper also needs to

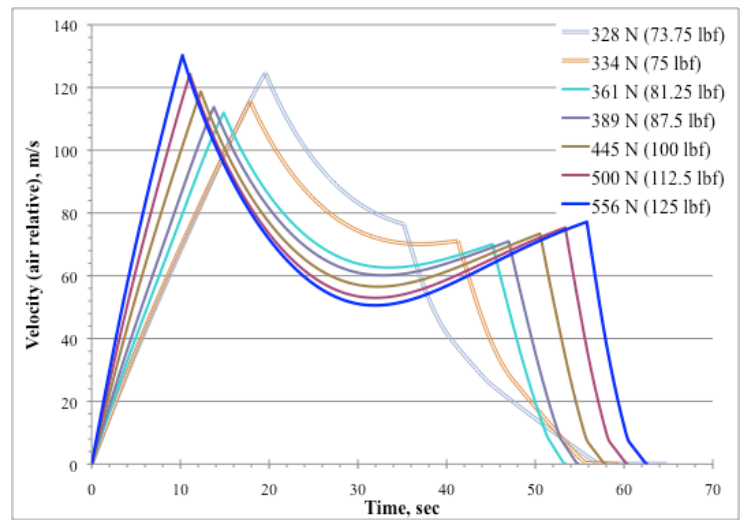

Figure 6. Vehicle thrust trade; velocity variations with maximum thrust level (Rev1 descent thrust profile). perform the pitch-up (to get into the vertical landing attitude) from a lower altitude and higher velocity while using a lower thrust level, also requiring a longer burn time. Below a maximum thrust level of $328 \mathrm{~N}$, the firstburn pitch-over maneuver becomes problematic because the hopper could end up in an unfavorable attitude at the end of the burn due to the excessive pitch-over. The second burn is likely to become a problem as well since there may simply not be enough altitude achieved during the ballistic coast to accomplish the landing burn per the ground rules.

As stated above, this analysis sets the required hop distance at $5 \mathrm{~km}$ as a stressing case. Shorter required hop distances may potentially be achieved with even lower maximum thrust levels. However, as Fig. 2 shows, shorter hop distances also have lower apex altitudes which, in turn, become a limiting factor for lower thrust levels, as described above. Another parameter of interest may be the hopper's mass; in this analysis, the hopper's initial (wet) mass is fixed at $30 \mathrm{~kg}$. Varying the hopper's mass will also have an impact on the thrust level and hop distance. A separate analysis was performed (below) to better understand the effects of hop distances and varying hopper masses.

Table III. Vehicle thrust trade summary results; $5 \mathrm{~km}$ hop distance (Rev1 descent thrust profile).

\begin{tabular}{|c|c|c|c|c|c|c|c|}
\hline Max. Thrust, N & Max. Thrust, lbf & Final mass, kg & Burn1, sec & Coast, sec & Burn2, sec & $\begin{array}{c}\text { Approx. Peak } \\
\text { Alt, } \mathrm{m}\end{array}$ & $\begin{array}{c}\text { Propellant } \\
\text { Consumed, } \mathrm{kg}\end{array}$ \\
\hline 556 & 125.00 & 27.02 & 10.23 & 45.59 & 6.75 & 1320 & 2.98 \\
501 & 112.50 & 27.13 & 11.08 & 42.30 & 6.99 & 1190 & 2.87 \\
445 & 100.00 & 27.22 & 12.31 & 38.23 & 7.36 & 1060 & 2.78 \\
389 & 87.50 & 27.33 & 13.78 & 33.24 & 7.85 & 881 & 2.67 \\
362 & 81.25 & 27.35 & 14.89 & 30.29 & 8.23 & 795 & 2.65 \\
334 & 75.00 & 26.91 & 17.86 & 23.40 & 18.16 & 766 & 3.10 \\
328 & 73.75 & 26.46 & 19.58 & 15.60 & 29.66 & 675 & 3.54 \\
\hline
\end{tabular}

There are two thrust level 'thresholds' identified in this analysis that represent critical levels for the assumed hopper mass, hop distance, and ground rules. At the first threshold, continuing to lower thrust no longer continues to optimize performance but instead causes propellant usage to increase sharply. At the second threshold, the thrust level is too low to achieve a meaningful hopper mission. Table III shows several performance metrics as a function of maximum thrust level. The propellant consumption data is also shown graphically in Fig. 5. Of particular interest are the burn times. Because burn times increase significantly with lower maximum thrust levels, the increased thermal stress on the engine is likely not worth the small reduction in propellant usage.

To assess the effects of the Rev2 descent burn thrust profile (Fig. 1), the hop distance was fixed at $1 \mathrm{~km}$. This change had a relatively small impact on performance, requiring only a 3.4 percent increase in propellant consumed. While the optimized spline thrust profile requires slightly less propellant, it will require a more complex command and control system for the engine and fast-response throttle valves. The prescribed thrust profile of Rev2 is a more natural thrust profile, and will be easier to implement in actual propulsion hardware operations. Therefore, the Rev2 thrust decay profile was used for the remaining trajectory analysis.

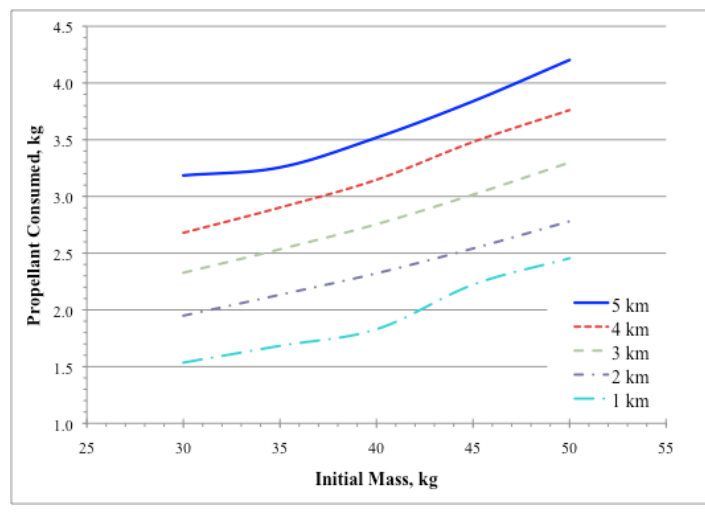

Figure 7. Propellant required as a function of initial mass and hop distance (Rev2 descent thrust profile). 


\section{Variation in Initial Mass}

With an initial determination of required propellant for a given hop, a preliminary estimate was made for the mass of the production plant and the dry mass of the hopper vehicle (including propulsion system, structure, and power system). This resulted in slightly higher initial vehicle wet mass than the $30 \mathrm{~kg}$ used for the preliminary trajectory analysis. Therefore, a second round of parametrics was performed for increasing initial mass. Each of the mass sweeps was performed for a range of hop distances from 1 to $5 \mathrm{~km}$ at $556 \mathrm{~N}$ thrust. Table IV shows the results of the initial mass and hop distance trade, and Fig. 7 graphically shows the propellant usage.
Table IV. Initial mass and hop distance trade results; $556 \mathrm{~N}$ (125 lbf) thrust (Rev2 descent thrust profile).

(Rev2 descent thrust profile).
\begin{tabular}{|c|c|c|c|c|c|c|c|}
\hline Initial Mass, kg & $\begin{array}{c}\text { Iop distance, } \\
\text { km }\end{array}$ & Final mass, kg & Burn1, sec & Coast, sec & Burn2, sec & $\begin{array}{c}\text { Approx. Peak } \\
\text { All, m }\end{array}$ & $\begin{array}{c}\text { Propellant } \\
\text { consumed, kg }\end{array}$ \\
\hline 30 & 1 & 28.47 & 3.90 & 25.78 & 6.91 & 406 & 1.54 \\
35 & 1 & 33.32 & 4.32 & 23.39 & 7.11 & 351 & 1.68 \\
40 & 1 & 38.17 & 4.77 & 21.28 & 7.25 & 307 & 1.83 \\
45 & 1 & 42.78 & 5.90 & 23.84 & 7.94 & 393 & 2.22 \\
50 & 1 & 47.55 & 6.63 & 23.01 & 8.30 & 385 & 2.46 \\
\hline 30 & 2 & 28.05 & 5.39 & 32.03 & 7.55 & 629 & 1.95 \\
35 & 2 & 32.87 & 5.92 & 28.76 & 7.90 & 536 & 2.13 \\
40 & 2 & 37.68 & 6.51 & 25.64 & 8.20 & 457 & 2.32 \\
45 & 2 & 42.46 & 7.21 & 23.05 & 8.56 & 403 & 2.54 \\
50 & 2 & 47.22 & 7.99 & 20.52 & 8.98 & 355 & 2.78 \\
\hline 30 & 3 & 27.67 & 6.93 & 37.47 & 7.97 & 868 & 2.33 \\
35 & 3 & 32.47 & 7.51 & 33.47 & 8.43 & 734 & 2.53 \\
40 & 3 & 37.25 & 8.19 & 29.70 & 8.87 & 622 & 2.76 \\
45 & 3 & 41.98 & 9.02 & 26.69 & 9.36 & 547 & 3.02 \\
50 & 3 & 46.70 & 9.97 & 23.42 & 9.90 & 473 & 3.30 \\
\hline 30 & 4 & 27.32 & 8.52 & 41.81 & 8.23 & 1090 & 2.68 \\
35 & 4 & 32.10 & 9.12 & 37.35 & 8.80 & 928 & 2.90 \\
40 & 4 & 36.85 & 9.87 & 32.98 & 9.34 & 781 & 3.15 \\
45 & 4 & 41.52 & 10.92 & 29.36 & 10.06 & 687 & 3.48 \\
50 & 4 & 46.24 & 11.89 & 25.82 & 10.59 & 584 & 3.76 \\
\hline 30 & 5 & 26.82 & 10.81 & 49.50 & 8.54 & 1540 & 3.19 \\
35 & 5 & 31.74 & 10.79 & 40.55 & 9.06 & 1110 & 3.26 \\
40 & 5 & 36.48 & 11.59 & 35.63 & 9.68 & 930 & 3.52 \\
45 & 5 & 41.16 & 12.62 & 31.91 & 10.35 & 812 & 3.84 \\
50 & 5 & 45.80 & 13.87 & 27.50 & 11.12 & 687 & 4.20 \\
\hline
\end{tabular}

Table V. Preliminary trade for large Hopper vehicle; $450 \mathrm{~kg}$ initial mass.

\begin{tabular}{|ccccccc|cc|}
\hline $\begin{array}{c}\text { Hop } \\
\text { distance, } \\
\text { km }\end{array}$ & $\begin{array}{c}\text { Final mass, } \\
\mathrm{kg}\end{array}$ & Burn1, sec & Coast, sec & Burn2, sec & $\begin{array}{c}\text { Approx. } \\
\text { Peak } \\
\text { Alt, km }\end{array}$ & $\begin{array}{c}\text { Propcllant } \\
\text { Consumed, } \\
\text { kg }\end{array}$ & $\begin{array}{c}\text { Max } \\
\text { Thrust, N }\end{array}$ & $\begin{array}{c}\text { Max } \\
\text { Thrust, lbf }\end{array}$ \\
\hline 10.0 & 401 & 14.0 & 40.5 & 14.6 & 1.29 & 49.3 & 5635 & 1267 \\
12.5 & 395 & 15.7 & 45.1 & 15.6 & 1.59 & 54.5 & 5646 & 1269 \\
15.0 & 391 & 17.3 & 49.6 & 16.5 & 1.91 & 59.2 & 5659 & 1272 \\
17.5 & 387 & 18.8 & 53.4 & 17.3 & 2.21 & 63.4 & 5653 & 1271 \\
\hline
\end{tabular}

\section{Larger Hopper Vehicle and Longer Hops}

As an initial attempt to assess a larger class Mars Hopper, an initial vehicle mass of $450 \mathrm{~kg}$ was assumed (15 times larger than the initial $30 \mathrm{~kg}$ hopper). For this larger hopper, the maximum thrust level was allowed to scale up to enable the heavier hopper to accomplish the mission; the $3^{\text {rd }}$ order decay descent burn throttle profile was preserved. Furthermore, the hop distance was allowed to increase into a feasible range of solutions. The combination of higher maximum thrust and increased hop distance along with an objective of minimizing the propellant used resulted in an examined range of hop distances from 10 to $17.5 \mathrm{~km}$. Table $\mathrm{V}$ shows the results for this larger Hopper and Fig. 8 shows graphs for the final mass, propellant consumed, total burn time,
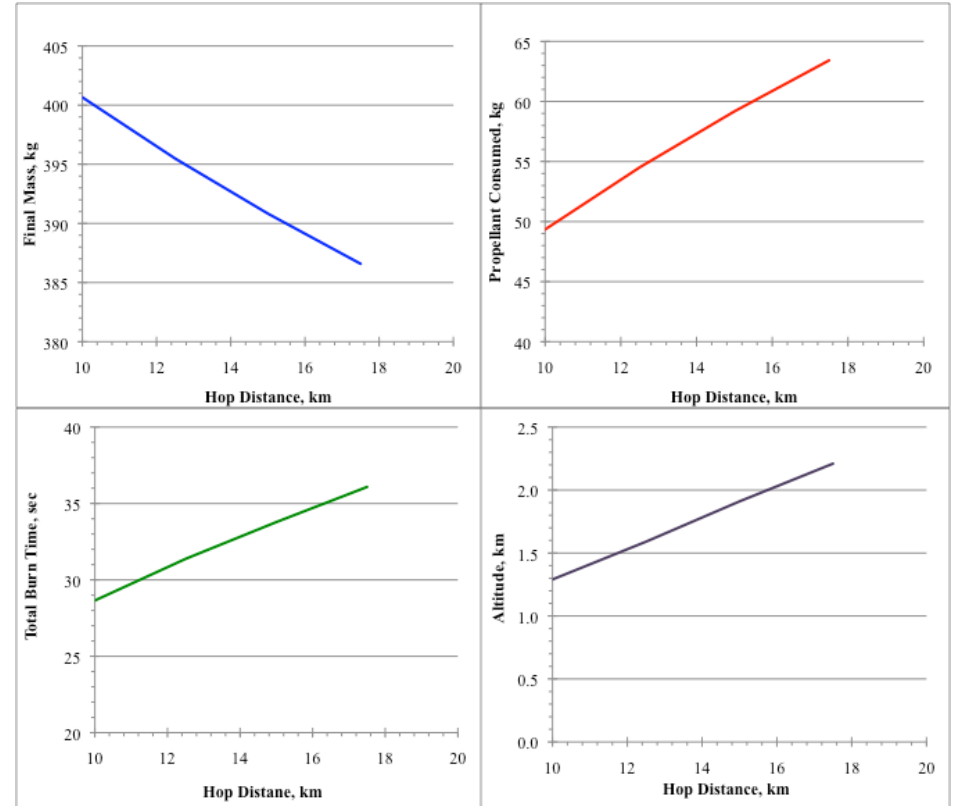

Figure 8. Large Hopper vehicle selected trade results; $450 \mathrm{~kg}$ initial mass (Rev2 descent thrust profile). 
and approximate peak altitude achieved during the hop. Performance (i.e., propellant consumed) appears fairly linear with hop distance. This larger Hopper model is intended as the starting point for examining larger weight class hoppers.

\section{Hopper Propulsion System}

A small propulsion system was assembled to demonstrate the operational and thrust performance of a lowcomplexity system suitable for long-term autonomous operation on Mars. The primary objective of the experimental tests was to demonstrate the ability to reliably set the initial conditions in the tanks and control mass flow rate such that the first burn provided a steady-state thrust level and the second burn provided a decaying thrust needed for a soft landing. Previous work on the hopper design with oxygen and carbon monoxide propellants envisioned that the propellants would be liquefied as they were produced and stored as cryogenic propellants. ${ }^{2}$ Follow on work to demonstrate such a small cryogenic propulsion system encountered difficulties in maintaining the quality of the liquid up to the thruster during an engine firing; this resulted in thrust variations caused by inconsistent flow rates during the engine firing. While cryogenic storage of the propellants will be required for a larger energy mission such as sample return and human ascent, the small propellant quantities required for the hopper investigated here allow for storage as a high-pressure gas. The two challenges that were investigated in this work were: 1) evaluating whether the required engine could be passively cooled, and 2) understanding the relationship between the propellant tank storage conditions and flow control device such that a predictable and repeatable naturally decaying thrust could be demonstrated on the second burn to provide the deceleration required for a soft landing.

\section{A. Engine Design and Thermal Analysis}

The gaseous oxygen-gaseous methane engine was designed for a nominal chamber pressure of $200 \mathrm{psi}$, which is low enough that the propellants can be pressure-fed into the chamber. Throat area for a given desired thrust level at Mars ambient conditions was determined based on an assumed combustion chamber efficiency $\left(\mathrm{C}^{*}\right)$ of 85 percent. The nozzle expansion ratio was set such that the exit pressure would be approximately equal to ambient pressure of 14.7 psia.

The injector is a single coaxial element consisting of a centered oxygen post and a fuel annulus. The size of the injector elements was based on a desired injector pressure drop of 10 to 20 percent of chamber pressure, combined with the desire to use standard size commercially available tubing. The oxygen post is a $1.27 \mathrm{~cm}$ OD x $0.165 \mathrm{~cm}$ wall SS304 tube turned down to $1.14 \mathrm{~cm}$ OD. The exit plane of the post is recessed approximately $0.635 \mathrm{~cm}$ from the interior face of the injector plate. The outer fuel annulus consists of a $1.59 \mathrm{~cm}$ OD x $0.165 \mathrm{~cm}$ wall SS304 tube welded to the back of the injector plate. The design flow rates, pressure drops, and injection speeds for the $125 \mathrm{lbf}$ engine are listed in Table VI.

Table VI. Engine design parameters.

\begin{tabular}{|l|c|c|}
\cline { 2 - 3 } \multicolumn{1}{c|}{} & Oxygen & Methane \\
\hline Design Flow Rate, gm/s & 132 & 39 \\
Injector Prcssurc Drop, psi & 23 & 39 \\
Injection Speed, m/s & 105 & 189 \\
\hline
\end{tabular}

Table VII. Burn times for $1 \mathrm{~km}$ hop at different thrust levels.

\begin{tabular}{|c|c|c|c|c|}
\hline Thrust, $\mathrm{N}$ & Thrust, lbf & Burn1, $\mathrm{s}$ & Coast, $\mathrm{s}$ & Burn2, $\mathrm{s}$ \\
\hline 445 & 100 & 4.6 & 22.2 & 5.4 \\
556 & 125 & 3.9 & 25.9 & 5.3 \\
\hline
\end{tabular}

The initial trajectory analysis showed that varying the thrust from 334 to $556 \mathrm{~N}$ ( 75 to $125 \mathrm{lbf}$ ) had minimal effect on the total propellant required. Therefore, the thrust level selected for the experimental tests was determined based on thermal issues. Burn times for a $445 \mathrm{~N}(100 \mathrm{lbf})$ and $556 \mathrm{~N}(125 \mathrm{lbf})$ engine for a $1 \mathrm{~km}$ hop are listed in Table VII. Any engine design must be able to withstand the heat loads associated with the hot fire thermal environment. Nickel 200 and Nickel 201 were both evaluated as potential materials, and Nickel 201 was selected for its combination of good thermal conductivity, good corrosion resistance, and good strength retention at high temperatures. A wall thickness of $0.635 \mathrm{~cm}$ was selected for the thermal analysis.

To evaluate the effect of thrust level on the engine design, a thermal model was developed to assess the design and make pre-test and post-test predictions. The thermal model is a customized Fortran code that simulates the transient 2D axisymmetric conduction in the nozzle wall and injector plate. The thermal conductivity of the Nickel 201 is modeled as a function of temperature.

The exterior surface of both the engine wall and injector plate are assumed to radiate to a $300 \mathrm{~K}$ environment and exchange heat via natural convection with the ambient air. Along the interior surfaces of the computational domain, the surfaces exchange heat with the hot combustion gases. The hot-side convection coefficient and recovery 
temperature is computed using results from the widely used Computer Program for Calculation of Complex Chemical Equilibrium Compositions and Applications (commonly called CEA). ${ }^{6}$

For the CEA analysis, the nozzle is discretized into 10 axial stations. At each station the local Mach number (M), Prandtl number $(\operatorname{Pr})$, thermophysical properties, and stagnation temperature are used to determine the recovery temperature $\left(\mathrm{T}_{\text {rec }}\right)$ according to:

$$
T_{r e c}=T_{o} \frac{1+\operatorname{Pr}^{1 / 3} \frac{\gamma-1}{2} M^{2}}{1+\frac{\gamma-1}{2} M^{2}}
$$

where $\gamma$ is the ratio of specific heats and $T_{o}$ is stagnation temperature. The heat transfer coefficient (h) along the hot wall is computed by either the Bartz correlation or the Colburn correlation:

$$
\begin{gathered}
h_{\text {bartz }}=0.026 \frac{\sigma}{D_{t}^{0.2}}\left(\frac{\mu^{0.2} C_{p}}{\operatorname{Pr}^{0.6}}\right)\left(\frac{\dot{m}}{A_{t}}\right)^{0.8}\left(\frac{D_{t}}{r_{\text {curve }}}\right)^{0.1}\left(\frac{A_{t}}{A}\right)^{0.9} \\
h_{\text {colburn }}=0.023 \operatorname{Re}^{0.8} \operatorname{Pr}^{0.3}
\end{gathered}
$$

where $\sigma$ is a correction factor for property variations across the boundary layer, $D_{t}$ is throat diameter, $\mu$ is viscosity, $C_{p}$ is the specific heat at constant pressure, $A_{t}$ is throat area, $r_{\text {curve }}$ is the radius of curvature at the throat, $A$ is the local area, and Re is the Reynolds number. The parameters in these expressions are evaluated from the results of the CEA analysis. The recovery temperature and heat transfer coefficient are computed at the 10 axial stations in the CEA analysis and linearly interpolated to the surfaces in the finite volume heat conduction model. Once the recovery temperature and heat transfer coefficient are calculated, the heat flux (q") at interior surfaces of the computational domain is determined by:

$$
q^{\prime \prime}=h\left(T_{\text {rec }}-T_{\text {wall }}\right)
$$

The finite volume model divides the computational domain into discrete finite volumes and solves the conservation of energy equation over each discretized volume. The solution marches out in time using an implicit backward Euler time stepping routine. The set of matrix equations is solved iteratively using incomplete LU (lower/upper, also called ILU) decomposition. The solution is converged within each time step when the $\mathrm{L}_{\infty}$ norm of the residual (maximum error in the residual over all computational nodes) decays six orders of magnitude.

The model can be run using either the Bartz correlation or the Colburn correlation to compute the hot side heat transfer coefficient. Additionally, the thermophysical properties of the mixture of combustion gases can be determined from CEA using either a frozen chemistry or equilibrium chemistry model. To assess the sensitivity of the thermal solution to these

\begin{tabular}{|c|c|c|c|}
\hline & Wall Temp, K & Flux, W/cm2 \\
\hline \multicolumn{2}{|c|}{ Experiment $(\mathrm{Pc}=300 \mathrm{psi})$} & 478 & 368 \\
\hline \multicolumn{4}{|l|}{ Predicted } \\
\hline \multirow{2}{*}{ Bartz correlation } & equilibrium chemistry & 797 & 1013 \\
\hline & frozen chemistry & 448 & 311 \\
\hline \multirow{2}{*}{ Colburn correlation } & equilibrium chemistry & 629 & 686 \\
\hline & frozen chemistry & 389 & 180 \\
\hline
\end{tabular}
options and validate the thermal model, experimental data from a gaseous

Table VIII. Validation of thermal model using $\mathbf{G O}_{2} / \mathbf{G H}_{2}$ data. oxygen/gaseous hydrogen combustor ${ }^{7}$ was compared with model predictions. Similar to the current Mars Hopper engine design, the validation experiment employed a single coaxial injector with a centered oxygen post. The propellants entered the combustion chamber, which was a heat sink design, at ambient temperature. Temperature and heat flux data were recorded 2 inches downstream of the injector face. The comparison in wall temperature and heat flux between the experiment and the model is shown in Table VIII where clearly the Bartz correlation with a frozen chemistry model in CEA yielded the 
best result. Thus, subsequent thermal modeling of the Mars Hopper engine used the Bartz heat transfer correlation in the finite volume thermal model and the frozen chemistry formulation in the CEA model.

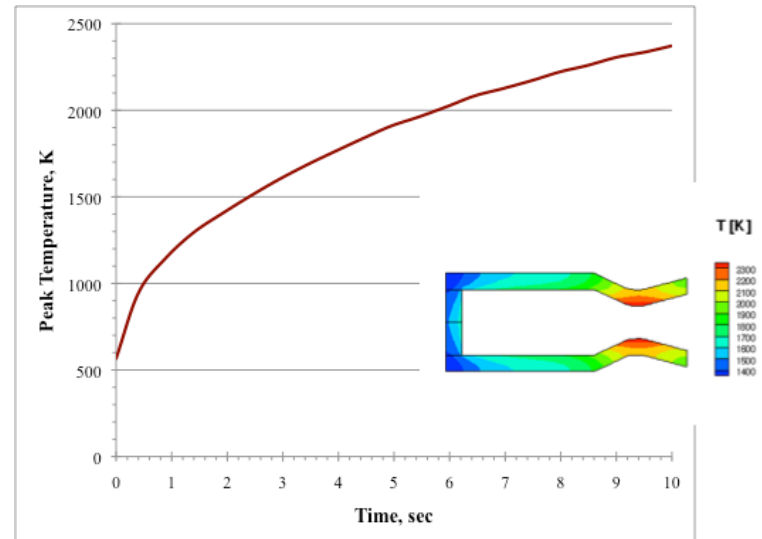

Figure 9. Thermal model predictions for a 10-sec burn of the Mars Hopper engine.

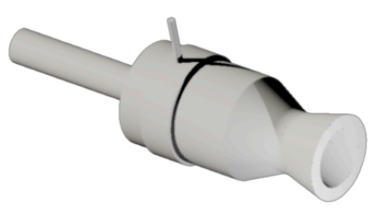

Figure 10. Solid model of Hopper engine.

To size the thrust level for the Mars Hopper engine, the validated thermal model simulated a $10 \mathrm{sec}$ burn. The peak temperature as a function of time and the temperature contours at the end of the simulation are shown in Fig. 9. Using the time history of peak temperature and an allowable material temperature of approximately $1700 \mathrm{~K}$, the results of the model indicate the first burn in the hopper trajectory should be limited to 4 sec. Consequently, for a downrange design distance of $1 \mathrm{~km}$, the thrust of the engine should be $556 \mathrm{~N}(125 \mathrm{lbf})$ as indicated in Table VII. For a thrust of $556 \mathrm{~N}$ at the surface of Mars, an ideal chamber pressure of 200 psia, and an assumed combustion efficiency of 85 percent, the throat diameter is $1.57 \mathrm{~cm}$. The contraction and expansion ratios are 4.89 and 3 respectively. A solid model of the engine is shown in Fig. 10.

\section{B. Propellant Feed System}

The desired flow rates for the oxygen and methane propellants were determined by the thrust level and the assumed engine performance efficiency as discussed above. The final flow rate target at the end of the second engine burn was set at 25 percent of maximum thrust based on previous experience with typical planetary descent profiles. The trajectory analysis determined the total propellant required to provide the necessary delta- $\mathrm{V}$ to achieve a given hop distance (dependent also on initial vehicle mass). A gaseous propellant feed system was designed and built to best meet the requirements for steady-state flow rate, final flow rate, and total propellant burned; a simplified schematic of the propulsion test system is shown in Fig. 11.

A very simple method to set and control flow rate in a gaseous feed system is to use a sonic orifice that delivers a known flow rate as long as the upstream pressure is greater than that required to maintain choked flow. The mass flow rate of an ideal gas through a choked orifice is given by:

$$
\dot{m}=C_{d} A \Phi \frac{P_{u}}{\sqrt{T}}
$$


where mdot is mass flow rate through the orifice, $\mathrm{C}_{\mathrm{d}}$ is discharge coefficient, $\mathrm{A}$ is the throat area of the sonic orifice, and $\mathrm{P}_{\mathrm{u}}$ and T are the pressure and temperature at the orifice inlet. Phi $(\Phi)$ is the sonic flow factor and defined by:

$$
\Phi=\sqrt{\gamma *\left(\frac{\gamma+1}{2}\right)^{(\gamma+1 / \gamma-1)} * \frac{g_{c}}{R}}
$$

From Eq. (5) it is clear that a constant flow rate can be maintained if the pressure upstream of the orifice is held constant, assuming there is little variation in temperature. A regulator was installed upstream of the sonic orifice to maintain a constant pressure for the first steady-state burn. Before a test firing, the regulator dome was loaded to the desired pressure using propellant gases, so no external pressurization control gas is needed. The dome pressure is then locked off so it remains constant throughout the run and is not affected by the decaying tank pressure. This setup provides a constant flow rate as long as the tank pressure is greater than the regulator pressure $\left(\mathrm{P}_{\mathrm{u}}\right.$ in Eq. $\left.(5)\right)$. Once the propellant tank pressure falls below the regulator set pressure, $\mathrm{P}_{\mathrm{u}}$ is no longer constant, and the mass flow rate decays proportionally with the declining pressure. (Temperature variations were minimal and will be discussed below). This decay in flow rate results in a decay in engine thrust, which is exactly what is needed for the second engine firing that provides vehicle deceleration during descent in preparation for a soft landing. By carefully selecting the initial pressure in the tank, the supply pressure remained above the regulator set pressure for the first engine burn, then dropped below the set pressure at the start of the second burn to provide sufficient thrust decay or throttling.

To determine the pressure decay rate a time-marching program was written to calculate mass flow rate out of the tank and the resultant change in tank pressure and temperature. Several relationships between mass, pressure, and temperature were evaluated, including isentropic, polytropic, isothermal, and some combination of these. Comparisons to data from cold flow blow-down tests indicated that the isentropic relationships provided the best match to actual results. Initial mass in a tank of given volume is calculated using the ideal gas law and an initial pressure and temperature. Mass flow rate out of the tank for the first time step is calculated using Eq. (5) assuming regulator set pressure and initial tank temperature. At the end of the first time step, a new total mass in the tank is determined by subtracting from the initial value the amount lost, calculated using the flow rate out over the time period. The new pressure and temperature in the tank is known through the isentropic relationships:

$$
\begin{gathered}
\frac{P}{P_{0}}=\left(\frac{m}{m_{0}}\right)^{\gamma} \\
\frac{T}{T_{0}}=\left(\frac{P}{P_{0}}\right)^{(\gamma-1) / \gamma}
\end{gathered}
$$

For the subsequent time steps, mass flow rate is calculated using the lower of either the regulator set pressure or the new tank pressure. Initially, this analysis was performed using the new tank temperature for the temperature in Eq. (5), but tests indicated that while the temperature in the tank did decline roughly as predicted by Eq. (8), there was sufficient thermal mass in the feed system that the temperature recovered to nearly its initial temperature by the time it reached the sonic orifice. Therefore, the mass flow calculations continued to use initial temperature throughout the engine burn

The initial mass in the tank is a function of the initial temperature and pressure and the tank volume. A larger tank volume at the same temperature and pressure begins with a larger initial mass, resulting in a slower decline in mass as a percentage of initial mass, and therefore a slower decline in tank pressure. Similarly, the larger tank would allow a lower initial pressure due to the slower pressure decay rate. Lower storage pressures would reduce the mass and power of the production plant compressors, but this would need to be balanced with the increased mass of the larger tanks. In addition, a lower initial pressure resulted in a lower final pressure at the end of the second engine burn, resulting in final flow rate and thrust that were much less than the target values of 25 percent of initial thrust. While the trajectory analysis did not evaluate final thrust levels below 25 percent for the $3^{\text {rd }}$ order descent throttle profile, there will be a minimum thrust below which a soft landing is not possible. 
The challenge in the design of this system then is to select the best combination of tank volume and sonic orifice throat area such that the tank pressure remains above the steady-state set pressure for the first engine burn, and provides a decay rate during the second engine burn that results in both the desired final flow rate/thrust and a total mass flow over both burns equal to the target value defined by the trajectory analysis.

Figure 12 shows two examples of the relationship between some of these variables for the gaseous oxygen feed line. The coast phase is not shown in these figures. The target mass flow rates at the start and end of the first burn and at the end of the second burn are indicated by the X symbols. The circles indicate the target for cumulative oxygen mass consumed at the end of each burn. The two curves show the calculated flow rate and cumulative mass from the analysis. The sonic orifice throat diameter is $0.381 \mathrm{~cm}$ for both graphs. In Fig. 12a, the tank volume is 7.6 liters ( 2 gallons) and the initial pressure is set at 2000 psia such that the tank pressure reaches the sonic orifice set pressure of 665 psia (determined by desired oxygen flow rate of $132 \mathrm{~g} / \mathrm{s}$ ) at the end of the 5.4 second first engine burn. The match to the final flow rate target is very good, with the predicted value only about 2 percent below the target. However, the predicted cumulative mass flowed is more than 11 percent below the target value obtained from the trajectory analysis. In Fig. 12b, the tank volume is increased to 11.4 liters (3 gallons), and the initial pressure is set at 1575 psia. In this case, the cumulative mass flow is much closer to the target, falling only 6 percent low. However, this is at the expense of a final mass flow rate more than 35 percent higher than the target value.
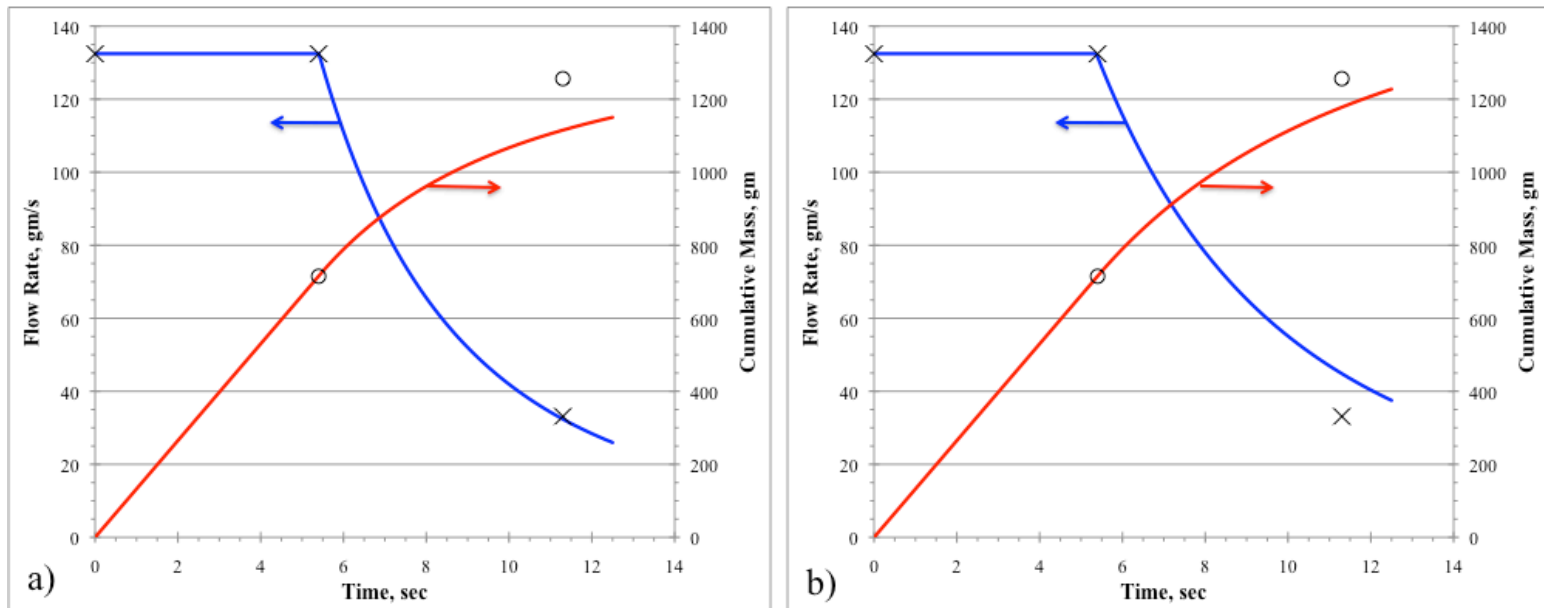

Figure 12. Example relationship between tank volume, initial pressure, and orifice diameter in matching target values for flow rate and cumulative mass flow for a) 7.6 liter tank, and b) 11.4 liter tank. (2000 psia initial pressure, $0.381 \mathrm{~cm}$ orifice.)

In Fig. 13, a larger sonic orifice is considered, with a throat diameter of $0.406 \mathrm{~cm}$. The larger diameter requires a lower set pressure of 585 psia to achieve the desired $132 \mathrm{~g} / \mathrm{s}$ flow rate. In Fig. 13a, a 11.4-liter tank and initial pressure of 1900 psia results in both final mass flow rate and final cumulative mass falling approximately 13 percent below the targets. In Fig. 13b, the initial tank pressure is increased to 2100 psia such that the second burn starts off with some period of steady-state thrust before starting to decay. This thrust scheme is similar to the results of the trajectory optimization with the $3^{\text {rd }}$ order throttle profile discussed above. In this case, both final values have moved closer to their targets, with the predicted final mass flow rate 7 percent high and the final cumulative mass coming up only 6 percent short.

Figures 12 and 13 show just a few of the variations that were evaluated before selecting conditions for the test hardware. Because the propellant feed system was designed and built before the final trajectory iterations were completed, and because of other limitations in the test cell, such as a limit on supply pressure, the conditions depicted in Fig. 13a were used for the engine tests mimicking a $2 \mathrm{~km}$ hop.

\section{Propulsion Experimental Results and Comparison to Predictions}

Twenty-two hot-fire tests were performed at sea level conditions, including 11 two-burn tests with a 'coast' period in between simulating both the 1-km and the 2-km hop profiles. A picture of a steady-state test is shown in figure 14. While the 2-burn profile for the longer hops could not be accomplished in a single run with the available run tanks (sized originally for the 1-km hop), the longer steady-state burns for the 3- and 5-km hops were performed to gather data on the thermal limit of the engine. Finally, the decay burn for the 5-km hop was also tested. The thrust performance of the engine was very low due to the simple single-element injector. While we assumed a combustion 

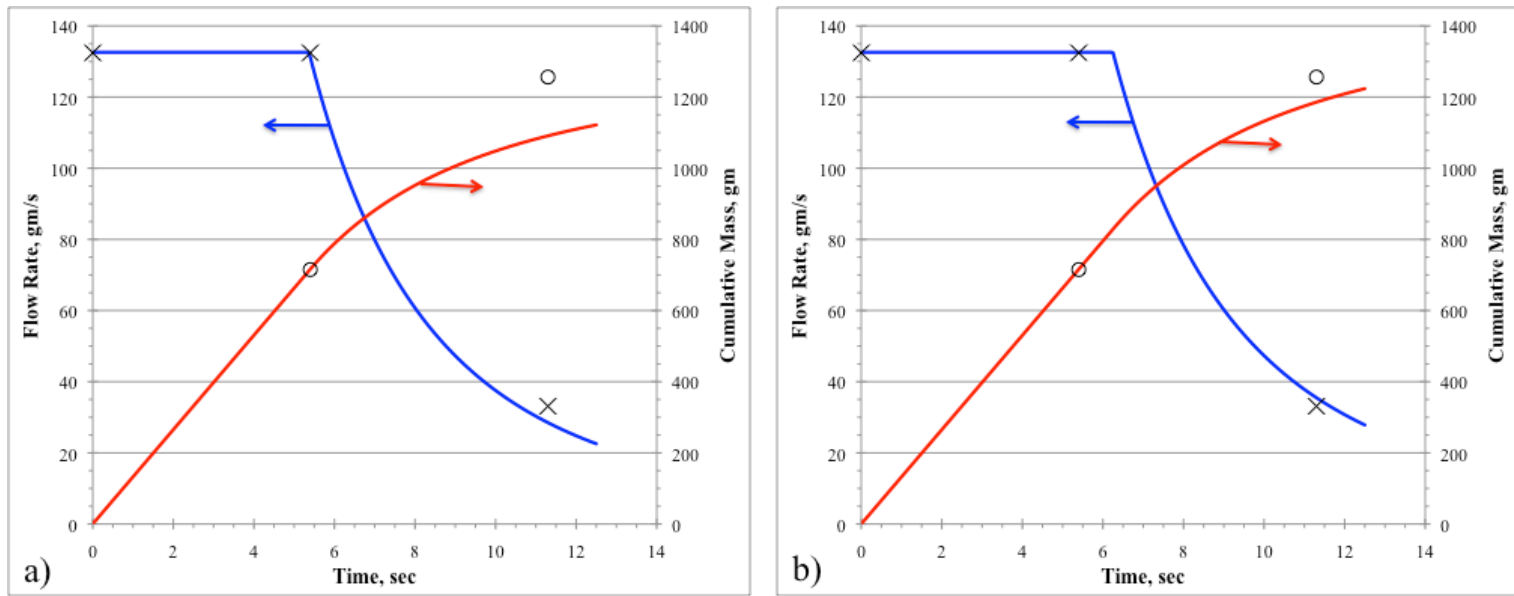

Figure 13. Additional options on propellant feed system components for $2 \mathrm{~km}$ hop for a) 1900 psia initial pressure, and b) 2100 psia initial pressure. $(0.406 \mathrm{~cm}$ orifice, 7.6 liter tank.)

efficiency of 85 percent in designing the engine, actual results were in the low 60's. It is clear that the combination of the propellant densities and mixture ratio of the oxygen/methane propellant combination are not amenable to a coaxial injector element with methane in the outer annulus. This test program was funded with internal IR\&D funds, and the coaxial element was the easiest to implement with the very low budget available. There are other injector element options that have been demonstrated in larger oxygen/methane engines that should bring the performance back into the desired range.

Figure 15 shows the oxygen and methane mass flow rates for a typical test run. The test profile was set to match the burn times for a $2-\mathrm{km}$ hop, with a target of 5.4 seconds for the first burn, a 32.1 second coast, and 5.9 seconds for the second burn. The decaying mass flow rate during the second burn

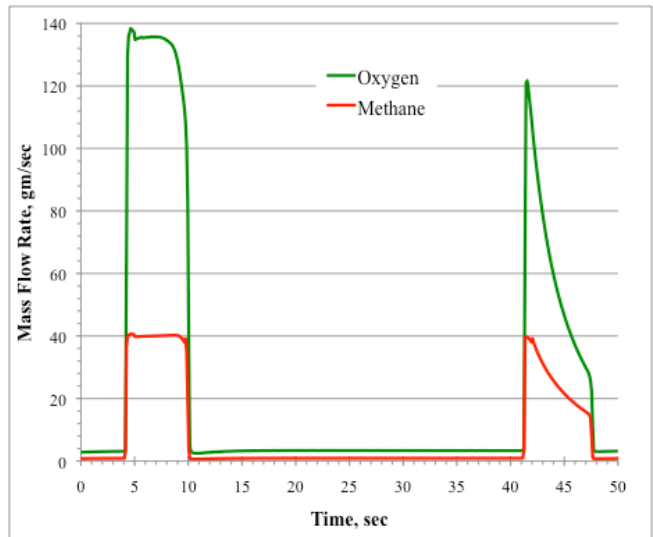

Figure 15. Oxygen and methane flow rates during a 2-burn test run simulating a 2km hop.

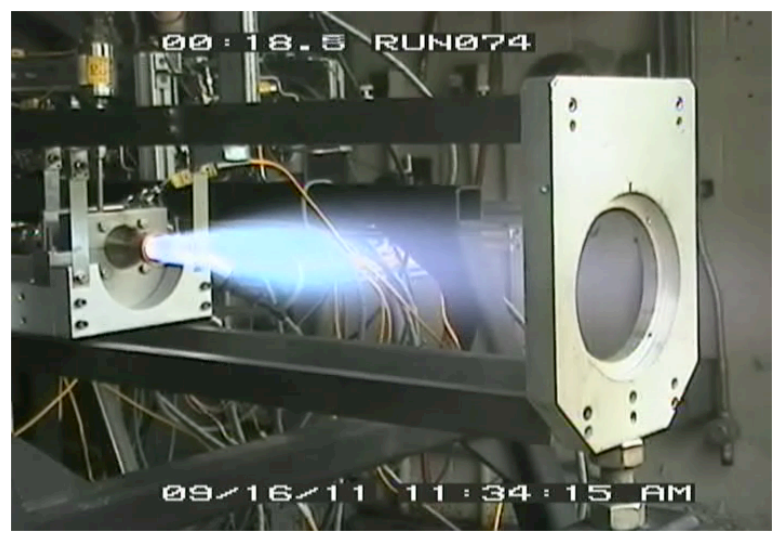

Figure 14. Mars Hopper engine hot-fire test.

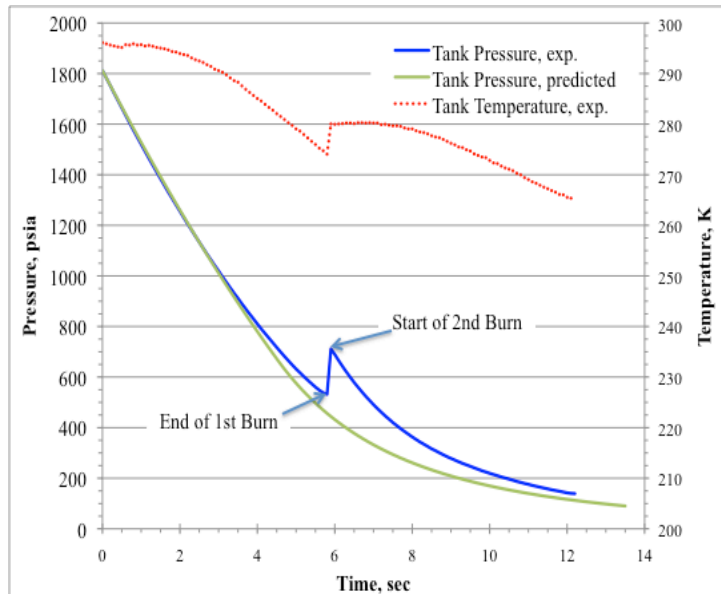

Figure 16. Comparison of predicted and experimental pressures for a 2-burn test simulating a 2-km hop. 
translated directly into a decaying thrust profile. In the figure, the methane flow rate begins the second burn at the same value as the steady-state first burn, but quickly begins to decline as the tank is drained below the steady-state set pressure for the sonic orifice. The main oxygen flow valve had a very slow response time. To compensate, it was commanded to close earlier than the methane valve, resulting in the apparent drop-off in flow rate near the end of the first burn. The flow rate starts off slightly lower for the second burn and immediately begins to decay, indicating a good prediction of pressure loss in the run tank.

Figure 16 shows a comparison of the oxygen tank pressure from this same run compared to that predicted by the pressurization program discussed above. The jump in the experimental pressure at around six seconds is actually a gradual rise that occurred during the 32-second coast period, which is not shown in the figure. During the first burn the gas temperature in the tank decreases due to expansion, and this contributes to the reduction in pressure. However, the thermal mass of the high-pressure metal tanks is significant, and the gas temperature draws heat from the tank walls to warm back up during the coast, thus causing the gradual increase in pressure that was measured. It is interesting to note that the predicted pressure decay matches fairly well to the actual decay during the first burn and by the end of the second burn, despite the predictions not modeling this coast period correctly. With this data, the model can now be improved to account for physical effects observed during the coast phase.

To assess the ability of the model to predict the thermal response of the nozzle, a number of comparisons were made between model predictions and experimental data. A type- $\mathrm{K}$ thermocouple was soldered to the exterior wall of the nozzle at the throat for the hot-fire tests. This location was monitored during the numerical simulation so that a comparison with data could be made. Initial comparisons revealed that the model over-predicted the nozzle wall temperature. This was most likely due to assumptions made for the heat transfer correlation used for the hotgas-side of the nozzle wall. The correlation assumes good mixing in the chamber during combustion. As noted above, the engine thrust and combustion efficiency was in the low 60 percent range instead of the 85 percent efficiency that was assumed during engine design. It is likely that poor mixing from the

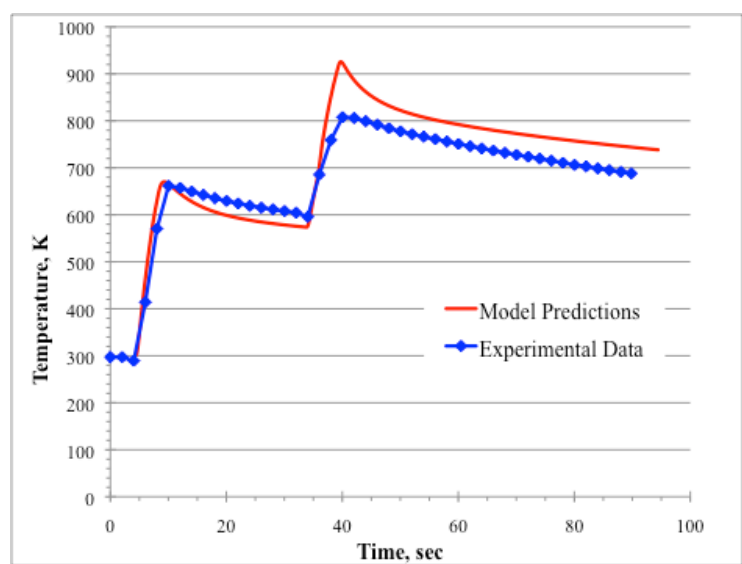

Figure 17. Comparison of predicted and experimental temperatures for a 2-burn test simulating a 1-km hop.

single co-axial injector element resulted in a fuel-rich zone near the chamber walls. To account for this in the thermal model, data from the steady state hot fires was used to scale the heat transfer coefficient. It was found that by reducing the heat transfer coefficient to 22 percent of its nominal value, comparison between the model and data was fair. A representative comparison is shown in Fig. 17 for a two-burn profile corresponding to a 1-km hop trajectory. The model over-predicts the peak temperature during restart, resulting in a higher thermal soak after the burn.

\section{Propellant Production Plant}

In addition to a reliable and robust propulsion system, a production plant that can make oxygen and methane from the atmospheric carbon dioxide is a critical element to prove the feasibility of the hopper concept. Although the genesis for designing a hopper that uses methane propellant stems from the recent data that indicates a significant amount of water is available in the Martian regolith, evaluation of a production system that includes excavation and extraction of the water from the regolith was beyond the scope of this effort. Therefore, in order to include realistic mass estimates for a complete hopper system, it was assumed that the hydrogen for 5 hops would be brought in separate high-pressure tanks. While earth-supplied hydrogen will limit the ultimate range of a hopper, the added complexity of harvesting the regolith may require that an initial demonstration not rely on this resource but only on the relatively easier to acquire atmospheric resource.

There has been significant work over the last several years in developing physics-based component models for a lunar propellant production system. ${ }^{8-10}$ Several of those components, such as the methanation reactor, reverse water gas shift reactor, and electrolyzer, are common to a Mars production plant. One option, therefore, to estimate the mass and power of the production plant was to use these component models where they exist. Unfortunately, the component models of interest on Mars have not yet been well validated with actual test data and hardware, 
especially at the extremely low production rates that are required for the small hopper vehicle. Therefore, the approach taken here was to search for existing parts that operate in the range of interest for the hopper and 'build' the production plant using mass and power values from actual hardware as much as possible.

\section{A. Production Plant Rates}

While the time spent performing scientific investigations at an exploration site before 'hopping' to the next site is a key factor in the sizing of the production plant, this was initially held constant at 30 days to limit the size of the trade space. Table IX lists the production rates for the large and small hoppers, and also shows the rate for a sample return ascent vehicle for comparison. ${ }^{11}$ The production plant for the large hopper vehicle would be $1 / 10^{\text {th }}$ scale of that for a sample return mission, and would therefore be a significant risk reduction mission to demonstrate the feasibility before relying on in-situ propellants in the critical path for sample return. The initial vehicle mass, hop distances, and propellant requirements were taken from the preliminary trajectory analysis and were used for sizing the production plant. The production plant mass was then used in the vehicle sizing, discussed below, which resulted in a better estimate for initial mass. While the initial vehicle mass estimates proved to be reasonable, several more iterations on trajectory, propulsion system and production plant mass, and vehicle sizing would be required to converge.

Table IX. Production rates for small and large hopper, and for one possible sample return mission option.

\begin{tabular}{|c|c|c|c|c|c|c|c|}
\hline Vehicle Type & $\begin{array}{c}\text { Initial Vehicle } \\
\text { Mass } \\
\text { kg }\end{array}$ & $\begin{array}{l}\text { Production } \\
\text { Time } \\
\text { days }\end{array}$ & $\begin{array}{l}\text { Hop Distance } \\
\text { km }\end{array}$ & $\begin{array}{l}\text { Propellant } \\
\text { per Hop } \\
\text { kg }\end{array}$ & $\begin{array}{l}\text { Oxygen } \\
\text { kg/day }\end{array}$ & $\begin{array}{c}\text { Methane } \\
\mathrm{kg} / \text { day }\end{array}$ & $\begin{array}{c}\text { Carbon } \\
\text { Dioxide* } \\
\text { kg/day }\end{array}$ \\
\hline Small Hopper & 30 & 30 & 2 & 1.9 & 0.049 & 0.014 & 0.084 \\
\hline I arge Hopper & 450 & 30 & 15 & 59.4 & 1.53 & 0.45 & 2.6 \\
\hline Sample Return & & 70 & N/A & 1000 & 11 & 3.2 & 25.3 \\
\hline
\end{tabular}

*Assumes $80 \%$ total efficiency of extracting oxygen from carbon dioxide

\section{B. Production Plant Components}

While minimizing the size of the production plant will be important for any Mars mission, it is even more critical if it will be carried from site to site on every hop. Therefore, the system evaluated here relied heavily on microchannel technology components such as those being developed by Battelle Memorial Institute ${ }^{11}$ and other

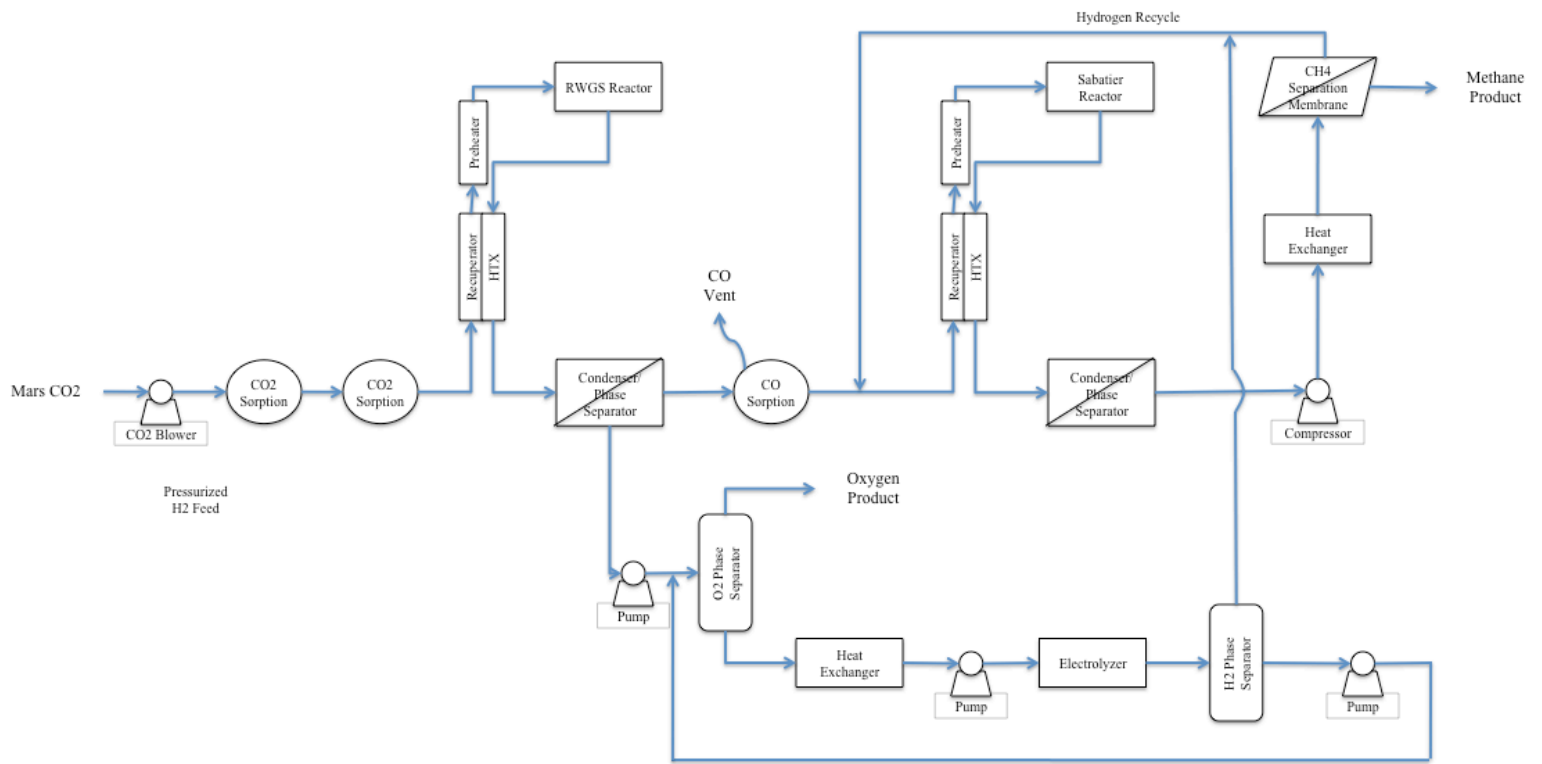

Figure 18. Simplified schematic of oxygen/methane in-situ production plant. 
companies. A simplified schematic of the production plant considered in this study is shown in figure 18 , taken from ref. 11. In this system, a Sabatier reactor produces methane and water from carbon dioxide and hydrogen, which is then electrolyzed to produce oxygen and hydrogen. The oxygen is stored in the run tanks, and the hydrogen is recycled back into the Sabatier process. This reaction produces oxygen and methane in a mass ratio of 2 to 1 , and it is generally desired to operate the rocket engine at a ratio between 3 and 3.8 to maximize performance. Several options have been proposed for generating extra oxygen to increase the mass ratio, such as solid oxide electrolysis and reverse water gas shift. The system evaluated here incorporated the reverse-water-gas-shift option as experimental hardware data was available on which to base the mass estimates.

Two options were considered for processing and storing the propellants into the tanks at high pressure (2000 psia). One option was to use cryocoolers to chill the tanks and liquefy the propellants as they are produced. Prior to engine firing, the tanks would then be allowed to warm up to Mars ambient temperatures resulting in the propellants converting into high-pressure gases. A second option was to use compressors to compress the gases into the tanks as they are produced. Demonstration of the cryocoolers would be directly applicable to the sample return mission which will most likely require a cryogenic propulsion system to minimize tank volume, but would be a more complex system requiring cryocoolers, heat exchangers, and the wasted energy of chilling and warming the tanks on every hop cycle. The compressors are a simpler option for the production rates evaluated here, and were selected for this analysis.

Tables X and XI list the mass and power for the major components for the small and large production plant, respectively, along with references to existing hardware that was used as the basis for the estimates. Units in the tables used for required flow rates are inconsistent as they were matched to the units used in the specifications for the individual components selected for the mass basis. Total production plant mass and power were increased by 20 percent to provide margin and account for un-sized components. The components covered in the tables are discussed briefly in the paragraphs below.

Atmosphere Blower/Compressor. While the primary compression of the carbon dioxide resource will be accomplished by sorption pumps, a low-volume blower will be required to ensure a constant supply of fresh atmosphere to the sorption pump, and to provide sufficient pressure to force flow through the filter and sorption pumps. This component remains the most elusive to evaluate. Typically, vacuum pumps are the only components that show specifications capable of operating with low pressures (i.e., less than 10 torr) on one side. However, these pumps typically discharge to atmospheric pressure or higher, which means that if used on Mars they should be able to compress the feed gas to the required working pressure, thus negating the need for either a sorption pump or $\mathrm{CO}_{2}$ freezer. The objective of using a sorption pump was to significantly reduce the mass and power of compression, and also to increase the lifetime by minimizing the number of moving parts, gears, and bearings. Commercial devices that are designed to blow air are typically not listed as operating at very low pressures, but the basic physics behind a simple muffin fan, for example, implies that the volumetric flow rate should be similar even at very low densities, although with minimal pressure rise. A small muffin fan with a volumetric flow rate two orders of magnitude greater than needed was included here as a placeholder for the $\mathrm{CO}_{2}$ blower, with the acknowledgement that this critical first component requires further investigation, preferably in a chamber simulating the Mars atmosphere.

Filter. The microchannel sorption device being developed by Battelle Memorial Institute can be designed such that medium size particles ( 1 to 10 microns) will pass through and can be exhausted with the non- $\mathrm{CO}_{2}$ constituents of the atmosphere (primarily argon and nitrogen). Smaller particles $(<1$ micron) may adhere to the sorbent matrix due to electrostatic forces, and can be occasionally cleaned off through back-pulsing. Particles larger than 10 microns could clog the matrix and need to be filtered out before entering. In reviewing references on the properties of the Martian dust, the effective radius of particles suspended in the atmosphere appears to be between 1 and 2 microns. ${ }^{12}$ Particles larger than this are primarily present only during dust storms, and it is therefore difficult to quantify the total number of particles greater than 10 microns that will be present in the atmospheric gases introduced to the production plant. It will be assumed that production will be suspended for the duration of a dust storm. A brief review of available fibrous and membrane filters reveals that for a pore size of 5 microns gaseous flow rates several orders of magnitude greater than that needed here can be achieved with negligible pressure drop and minimal mass.

$\mathrm{CO}_{2}$ Acquisition/Compression. The sorption pumps included here are based on the Battelle microchannel sorption pumps. The basic concept of a sorption pump is to adsorb the atmospheric $\mathrm{CO}_{2}$ at low temperature and then warm the material to release it at high temperature to compress to a pressure amenable to the downstream reactors. While sorption pumps have been evaluated in the past, the general premise was to use the cold nighttime temperatures to adsorb during the night and then warm and release in the morning as processing operations are restarted. With this concept, the sorption material must be sized to contain an entire day's worth of $\mathrm{CO}_{2}$, which often drove the size of the units to be large and heavy. The Battelle concept uses a pressure and temperature swing method 
Table X. Production plant component mass and power estimates for small Hopper vehicle (2-km hop every 30 days).

\begin{tabular}{|c|c|c|c|c|c|c|c|c|c|c|c|}
\hline & \multicolumn{4}{|c|}{ Existing Hardware Reference } & \multicolumn{7}{|c|}{ Small hopper production plant - 2-km hop everv 30 davs } \\
\hline Component & $\begin{array}{c}\text { Mass, } \\
\text { kg }\end{array}$ & \begin{tabular}{|c|} 
Elect. \\
Power, \\
W
\end{tabular} & Capacity & Source & $\begin{array}{l}\text { Required } \\
\text { Capacity }\end{array}$ & $\begin{array}{l}\text { Mass } \\
\text { each, } \\
\text { kg }\end{array}$ & $\begin{array}{l}\text { Power } \\
\text { each, } \\
\text { W }\end{array}$ & Quantity & $\begin{array}{c}\text { Total } \\
\text { Mass, } \\
\text { kg }\end{array}$ & $\begin{array}{l}\text { Total } \\
\text { Power, } \\
\text { W }\end{array}$ & Rationale \\
\hline CO2 Feed Blower & 0.24 & 2.2 & $60 \mathrm{CFM}$ & note 1 & $\begin{array}{c}0.228 \mathrm{cfm} \\
\mathrm{CO} 2 \text { at } 7 \mathrm{torr} ; \\
0.002 \mathrm{scfm}\end{array}$ & 0.24 & 2.2 & 1 & 0.24 & 2.2 & $\begin{array}{l}\text { Need to verify operability and capacity } \\
\text { at low pressure, pressure drop across } \\
\text { filter }\end{array}$ \\
\hline Filter & & & & & & TBD & & & & & \\
\hline $\begin{array}{l}\text { Microchannel CO2 Sorption } \\
\text { Pumps }\end{array}$ & 1.290 & $\begin{array}{c}22-143 \\
(100-80 \% \\
\text { recup. eff. })\end{array}$ & $\left|\begin{array}{l}95 \mathrm{~g} / \mathrm{hr} \mathrm{CO} 2 \\
(\sim 10 \mathrm{x} \\
\text { compression })\end{array}\right|$ & $\begin{array}{l}\text { note } 2 \text {, Table } \\
\text { A.1, pg } 150 \text {, as } \\
\text { built }\end{array}$ & $7 \mathrm{~g} / \mathrm{hrCO} 2$ & 0.65 & 11 & 2 & 1.3 & 22 & $\begin{array}{l}\text { Assume could reduce mass by half for } \\
1 / 10 \text { th the rate; } 2 \text {-stage compression to } \\
100 x ; \text { heat (power) of } \\
\text { adsorption/desorption scales linearly - } \\
\text { assume } 80 \% \text { thermal recuperation } \\
\text { efficiency }\end{array}$ \\
\hline Microchannel RWGS Reactor & 0.050 & & $\begin{array}{l}154.1 \mathrm{~g} / \mathrm{hr} \\
\mathrm{H} 2 \mathrm{O}\end{array}$ & $\begin{array}{l}\text { note } 2 \text { Table } \\
5.7, \text { pg } 96 \& \\
101, \text { as-built } \\
\end{array}$ & $1.9 \mathrm{~g} / \mathrm{hr} \mathrm{H} 2 \mathrm{O}$ & 0.050 & & 1 & 0.05 & 0 & $\begin{array}{l}\text { Use demonstrated value for larger } \\
\text { capacity until further development } \\
\text { provides scaling }\end{array}$ \\
\hline Heat exchanger for RWGS & 0.060 & & & $\begin{array}{l}\text { note } 2, \text { Table } \\
5.7, \text { pg } 96 \& \text { \& } \\
101, \text { as-built } \\
\end{array}$ & & 0.040 & & 1 & 0.04 & 0 & $\begin{array}{l}\text { Use demonstrated value for larger } \\
\text { capacity (Sabatier) unit until further } \\
\text { development provides scaling }\end{array}$ \\
\hline Microchannel Sabatier Reactor & 0.090 & & $\begin{array}{l}48.7 \mathrm{~g} / \mathrm{hr} \\
\mathrm{CH} 4\end{array}$ & $\begin{array}{c}\text { note 2, Table } \\
5.2, \mathrm{pg} 85 \& \\
87, \text { as-built } \\
\end{array}$ & $1.2 \mathrm{~g} / \mathrm{hr} \mathrm{CH} 4$ & 0.045 & & 1 & 0.045 & 0 & $\begin{array}{l}\text { Assume could reduce mass by half for } \\
2.5 \% \text { of flow rate }\end{array}$ \\
\hline Heat exchanger for Sabatier & 0.040 & & & $\begin{array}{l}\text { note } 2 \text {, Table } \\
5.2, \mathrm{pg} 85 \& \\
87, \text { as-built } \\
\end{array}$ & & 0.040 & & 1 & 0.04 & 0 & $\begin{array}{l}\text { Use demonstrated value for larger } \\
\text { capacity until further development } \\
\text { provides scaling }\end{array}$ \\
\hline CO Removal & & & & & & TBD & & & & & \\
\hline \multirow[b]{2}{*}{ Electrolyzer } & 0.068 & 2 & $\begin{array}{l}0.3375 \mathrm{~g} / \mathrm{hr} \\
\mathrm{H} 2 \mathrm{O} \\
\text { electrolyzed }\end{array}$ & note 3 & \multirow[b]{2}{*}{$4.6 \mathrm{~g} / \mathrm{hr} \mathrm{H} 2 \mathrm{O}$} & \multirow[b]{2}{*}{1.0} & \multirow[b]{2}{*}{28.0} & \multirow[b]{2}{*}{1} & \multirow[b]{2}{*}{1} & \multirow[b]{2}{*}{28} & \multirow{2}{*}{$\begin{array}{l}1 \mathrm{~kg} \text { scaled up from small unit; } 0.6 \mathrm{~kg} \\
\text { scaled down from large unit; } 6 \mathrm{~W} / \\
(\mathrm{gm} / \mathrm{hr}) \text { electrolyzed for power } \\
\text { consistant with both units }\end{array}$} \\
\hline & 2.800 & 120 & \begin{tabular}{|l|}
$21.6 \mathrm{~g} / \mathrm{hr}$ \\
$\mathrm{H} 2 \mathrm{O}$ \\
electrolyzed \\
$(1$ cell unit $)$ \\
\end{tabular} & note 4 & & & & & & & \\
\hline $\begin{array}{l}\text { Microchannel } \\
\text { Condenser/Phase Separator }\end{array}$ & & & & & & TBD & & & & & \\
\hline Microchannel Recuperators & & & & & & TBD & & & & & \\
\hline Pumps & 0.360 & 19.7 & $\begin{array}{l}0.6181 / \mathrm{min} \\
\text { to } 125 \mathrm{psid} \text { at } \\
2400 \mathrm{rpm}\end{array}$ & note 5 & \begin{tabular}{|l|}
$0.03081 / \mathrm{min}$ \\
(assumes $400 \mathrm{x}$ \\
flow through \\
electrolyzer) \\
\end{tabular} & 0.36 & 20 & 3 & 1.08 & 60 & $\begin{array}{l}\text { existing pump is more than order-of- } \\
\text { magnitude greater flow rate, but at lower } \\
\text { delta P }\end{array}$ \\
\hline Recycle Compressor & 0.060 & 3.25 & $\begin{array}{l}12 \text { psi delta-P } \\
\text { at } \sim 0.4 \text { scfh }\end{array}$ & note 6 & $\begin{array}{l}0.059 \mathrm{scth} \\
\mathrm{CH} 4\end{array}$ & 0.06 & 3.25 & 1 & 0.06 & 3.25 & $\begin{array}{l}\text { Use mass and power as is from AP-3P04 } \\
\text { compressor }\end{array}$ \\
\hline Storage compressor - oxygen & \multirow{2}{*}{2.7} & \multirow{2}{*}{373} & \multirow{2}{*}{$\begin{array}{l}12-17 \mathrm{scfh} \\
5945 \mathrm{psig} \\
\text { outlet } \\
\text { pressure }\end{array}$} & \multirow{2}{*}{ note 7} & 0.102 scth $\mathrm{O} 2$ & 2.7 & 20 & 1 & 2.7 & 20 & \multirow{2}{*}{$\begin{array}{l}\text { At lower limit of mass based on curve } \\
\text { fit from family of compressors. Reduce } \\
\text { mass } 30 \% \text { assuming can accomplish } \\
\text { with fewer stages; Manufacturer } \\
\text { estimate of power for lower flow rates = } \\
11 \mathrm{~W} \text { (doubled here for conservatism). }\end{array}$} \\
\hline Storage compressor - methane & & & & & $\begin{array}{l}0.059 \mathrm{scfh} \\
\mathrm{CH} 4\end{array}$ & 2.7 & 20 & 1 & 2.7 & 20 & \\
\hline \multicolumn{5}{|l|}{ Table Notes: } & \multicolumn{4}{|l|}{ Totals: } & 11.1 & 187 & \\
\hline \multicolumn{12}{|c|}{ 1. Comair Rotron; catalog \#032140 (http://parts.digikey.com/1/pats/437691-fan-12vdc-muffin-mc12e3-032140.html) } \\
\hline \multicolumn{12}{|c|}{ 2. Paper reference 11} \\
\hline \multicolumn{12}{|c|}{ 3. Horizon Fuel Cell Technologies (www.horizonfuelcell.com/education_kits.htm) } \\
\hline \multicolumn{12}{|c|}{ 4. Giner electrolyzer EHP-0050-5001 Specifications sheet (Rev. 12-15-10) } \\
\hline \multicolumn{12}{|c|}{ 5. Micropump series GB-P25 (www.micropump.com/product_detail.aspx?ProductID=54) } \\
\hline 6. Smart Products AP-3P04 (wv & v.smartpr & ducts.com/pur & umps.php) & & & & & & & & \\
\hline
\end{tabular}

combined with integrated microchannel heat exchangers in a multi-bed unit. Preliminary work has shown the feasibility of rapid cycles on the order of 2 minutes with very efficient heat transfer from one unit to the next in an 8unit system, resulting in little external power requirement after initial heat-up. ${ }^{11}$ With the short cycles, the total amount of adsorbant can be significantly reduced, resulting in a very compact and lightweight unit. Tests at PNNL demonstrated a 10-times increase in pressure at a throughput of $95 \mathrm{~g} / \mathrm{hr}$ for a single unit with a mass of $1.3 \mathrm{~kg}$. This is about 10-times the throughput required for the small hopper production plant and about half that required for the large hopper plant. Half of the mass of the as-built unit was assumed for a conservative estimate of a $1 / 10^{\text {th }}$ throughput, and the actual mass was doubled for a doubling of the throughput.

Sabatier Reactor and Heat Exchanger. The microchannel Sabatier reactor built and demonstrated by Battelle produced $48.7 \mathrm{~g} / \mathrm{hr}$ of methane. The small hopper vehicle requires $1.2 \mathrm{~g} / \mathrm{hr}$ of methane and the large hopper vehicle requires $37.5 \mathrm{~g} / \mathrm{hr}$. As these microchannel reactors largely scale linearly with production rate, we assumed that the mass could be cut in half for a production rate of only 2.5 percent of the as-built unit. For the larger hopper, we used the mass of the as-built unit as the production rates were similar.

Reverse Water Gas Shift Reactor (RWGS). Assuming an oxygen-to-methane mixture ratio in the engine of 3.4, the reverse water gas shift reactor needs to produce $1.9 \mathrm{~g} / \mathrm{hr}$ water for the small hopper and $59 \mathrm{~g} / \mathrm{hr}$ for the large hopper, which is electrolyzed to provide the required extra oxygen. The microchannel RWGS reactor built and 
demonstrated by Battelle produced $154 \mathrm{~g} / \mathrm{hr}$ water, which is three times the required production rate of the large hopper, and close to 2 orders of magnitude greater than that needed for the small vehicle. However, it is difficult to imagine a unit much lighter than the $50 \mathrm{gm}$ of the as-built hardware, and therefore that mass was used for the plant for both vehicles. The mass for the heat exchanger in the RWGS loop here was taken from that used in the Sabatier reactor tests at PNNL.

Table XI. Production plant component mass and power estimates for large Hopper vehicle (15-km hop every 30 days).

\begin{tabular}{|c|c|c|c|c|c|c|c|c|c|c|c|}
\hline & \multicolumn{4}{|c|}{ Existing Hardware Reference } & \multicolumn{7}{|c|}{ Large hopper production plant - 15-km hop every 30 days } \\
\hline Component & $\begin{array}{l}\text { Mass, } \\
\text { kg }\end{array}$ & $\begin{array}{l}\text { Electric. } \\
\text { Power, } \\
\text { W }\end{array}$ & Capacity & Sourec & $\begin{array}{l}\text { Required } \\
\text { Capacity }\end{array}$ & $\begin{array}{l}\text { Mass } \\
\text { each, } \\
\mathrm{kg}\end{array}$ & $\begin{array}{l}\text { Powcr } \\
\text { cach, } \\
\text { W }\end{array}$ & Quantity & $\begin{array}{l}\text { Total } \\
\text { Mass, } \\
\text { kg }\end{array}$ & $\begin{array}{c}\text { Total } \\
\text { Power, } \\
\text { W }\end{array}$ & Rationalc \\
\hline $\mathrm{CO} 2$ Feed Blower & 0.24 & 2.2 & $60 \mathrm{CFM}$ & ref. 1 & $\begin{array}{l}7.2 \text { CFM CO2 } \\
\text { at } 7 \text { torr; } 0.066 \\
\text { SCFM }\end{array}$ & 0.24 & 2.2 & 1 & 0.24 & 2.2 & $\begin{array}{l}\text { Need to verify operability and capacity } \\
\text { at low pressure, pressure drop across } \\
\text { tilter }\end{array}$ \\
\hline Filter & & & & & & TBD & & & & & \\
\hline $\begin{array}{l}\text { Microchannel } \mathrm{CO} 2 \text { Sorption } \\
\text { Pumps }\end{array}$ & 1.290 & $\begin{array}{l}22-143 \\
(100-80 \% \\
\text { recup. eff. })\end{array}$ & $\begin{array}{l}95 \mathrm{~g} / \mathrm{hr} \mathrm{CO} 2 \\
(\sim 10 \mathrm{x} \\
\text { compression) }\end{array}$ & $\begin{array}{l}\text { ref. 2, Table } \\
\text { A.1, pg } 150 \text {, as } \\
\quad \text { built }\end{array}$ & $\begin{array}{l}220 \mathrm{gm} / \mathrm{hr} \\
\mathrm{CO} 2\end{array}$ & 2.6 & 172 & 2 & 5.2 & 344 & $\begin{array}{l}\text { Assume can double sortion rate with } \\
\text { double mass (should be less than double } \\
\text { because there is some minimum mass } \\
\text { value, i.e., non-zero y-intercept); heat } \\
\text { (power) of adsorption/desorption scales } \\
\text { linearly - assume } 90 \% \text { thermal } \\
\text { recuperation efficiency for } 2 \text { nd gen } \\
\text { system }\end{array}$ \\
\hline Microchannel RWGS Reactor & 0.050 & & $\begin{array}{l}154.1 \mathrm{~g} / \mathrm{hr} \\
\mathrm{H} 20\end{array}$ & $\begin{array}{l}\text { ref. } 2, \text { Table } \\
5.7, \text { pg } 96 \& \\
101, \text { as-built } \\
\end{array}$ & $59 \mathrm{~g} / \mathrm{hr} \mathrm{H} 2 \mathrm{O}$ & 0.050 & & 1 & 0.050 & 0 & $\begin{array}{l}\text { Use demonstrated value for larger } \\
\text { capacity until further development } \\
\text { provides scaling }\end{array}$ \\
\hline Heat exchanger for RWGS & 0.060 & & & $\begin{array}{l}\text { ref. } 2 \text {, Table } \\
5.7, \text { pg } 96 \& \\
101, \text { as-built } \\
\end{array}$ & & 0.040 & & 1 & 0.040 & 0 & $\begin{array}{l}\text { Use demonstrated value forunit with } \\
\text { similar capacity (Sabatier subsystem) }\end{array}$ \\
\hline Microchannel Sabatier Reactor & 0.090 & & $\begin{array}{l}48.7 \mathrm{~g} / \mathrm{hr} \\
\mathrm{CH} 4\end{array}$ & $\begin{array}{l}\text { ref. } 2 \text {, Table } \\
5.2, \text { pg } 85 \& \\
87, \text { as-built } \\
\end{array}$ & $37.5 \mathrm{~g} / \mathrm{hr} \mathrm{CH} 4$ & 0.090 & & 1 & 0.090 & 0 & $\begin{array}{l}\text { Use demonstrated value for unit with } \\
\text { similar capacity }\end{array}$ \\
\hline Heat exchanger for Sabatier & 0.040 & & & $\begin{array}{l}\text { ref. } 2, \text { Table } \\
5.2, \text { pg } 85 \& \\
87, \text { as-built } \\
\end{array}$ & & 0.040 & & 1 & 0.040 & 0 & $\begin{array}{l}\text { Use demonstrated value for unit with } \\
\text { similar capacity }\end{array}$ \\
\hline CO Removal & & & & & & TBD & & & & & \\
\hline Electrolyzer & $1.8-4.0$ & & $\begin{array}{l}21.6 \mathrm{~g} / \mathrm{hl}- \\
260 \mathrm{~g} / \mathrm{hr} \mathrm{H} 2 \mathrm{O} \\
\text { electrolyzed } \\
(1 \text { to } 12 \text { cell } \\
\text { stacks) }\end{array}$ & ref. 3 & $143 \mathrm{~g} / \mathrm{hr} \mathrm{H} 2 \mathrm{O}$ & 3.4 & 840 & 1 & 3.4 & 840 & $\begin{array}{l}\text { Curve fit from ref. } 3 \text { series EHP-0050- } \\
5001 \text { (require } \sim 7 \text { cell stack); } 60 \text { amps, } \\
2 \text { volts per cell }\end{array}$ \\
\hline $\begin{array}{l}\text { Microchannel } \\
\text { Condenser/Phase Separator }\end{array}$ & & & & & & TBD & & & & & \\
\hline Microchannel Recuperators & & & & & & TBD & & & & & \\
\hline Pumps & 0.360 & 54 & $\begin{array}{l}1.685 \mathrm{l} / \mathrm{min} \\
\text { to } 125 \mathrm{psid} \text { at } \\
4000 \mathrm{rpm}\end{array}$ & ref. 4 & $\begin{array}{l}0.953 \mathrm{l} / \mathrm{min} \\
\text { (assumes } 400 \\
\text { times flow } \\
\text { through } \\
\text { electrolyzer) } \\
\end{array}$ & 0.36 & 54 & 3 & 1.08 & 162 & $\begin{array}{l}\text { existing pump is more than order-of- } \\
\text { magnitude greater flow rate, but at lower } \\
\text { delta P }\end{array}$ \\
\hline Recycle Compressor & 0.227 & $<12 \mathrm{~W}$ & \begin{tabular}{|l} 
l6 psi \\
pressure \\
'drop' at 2 \\
scth \\
\end{tabular} & ref. 5 & $\begin{array}{l}1.85 \mathrm{SCFH} \\
\mathrm{CH} 4\end{array}$ & 0.23 & 12 & 1 & 0.23 & 12 & SP- 8000 \\
\hline Storage compressor - oxygen & \multirow{2}{*}{2.7} & \multirow{2}{*}{373} & \multirow{2}{*}{$\begin{array}{l}12-17 \mathrm{scfh} \\
5945 \text { psig } \\
\text { outlet } \\
\text { pressure }\end{array}$} & \multirow{2}{*}{ ref. 6} & $3.14 \mathrm{CFH} \mathrm{O} 2$ & 2.7 & 30 & 1 & 2.7 & 30 & \multirow{2}{*}{$\begin{array}{l}\text { Use the mass for Rotec I series as } \\
\text { required flow range is same order of } \\
\text { magnitude. Manufacturer estimate of } \\
\text { power for lower flow rates }=11 \mathrm{~W} \\
\text { (tripled here for conservatism). }\end{array}$} \\
\hline Storage compressor - methane & & & & & $1.85 \mathrm{CFH} \mathrm{CH} 4$ & 2.7 & 30 & 1 & 2.7 & 30 & \\
\hline \multicolumn{5}{|l|}{ Table Notes: } & \multicolumn{4}{|l|}{ Totals } & 18.8 & 1704 & \\
\hline \multicolumn{12}{|c|}{ 1. Comair Rotron; catalog \#032140 (http://parts.digikey.com/1/pats/437691-fan-12vdc-muffin-mc12e3-032140.html) } \\
\hline \multicolumn{12}{|c|}{ 2. Paper reference 11} \\
\hline \multicolumn{12}{|c|}{ 3. Giner electrolyzer EHP-0050-5001 Specifications sheet (Rev. 12-15-10) } \\
\hline \multicolumn{12}{|c|}{$\begin{array}{l}\text { 4. Micropump series GB-P25 (www.micropump.com/product_detail.aspx?ProductID=54) } \\
\text { 5. Smart Products SP- } 8000 \text { series (www.smartproducts.com/pumps.php) }\end{array}$} \\
\hline \multicolumn{12}{|c|}{ 5. Smart Products SP-8000 series (www.smartproducts.com/pumps.php) } \\
\hline
\end{tabular}

Electrolyzer. Two small commercially available PEM water electrolyzers were considered as a basis for mass and power estimates here. A very small unit from Horizon Fuel Cell Technologies can electrolyze $0.3375 \mathrm{~g} / \mathrm{hr}$ water and weighs only $68 \mathrm{gm}$. A slightly larger unit from Giner can electrolyze $21.6 \mathrm{~g} / \mathrm{hr}$ water in a single-cell unit and weighs $2.8 \mathrm{~kg}$. The small hopper vehicle requires an electrolysis rate of $4.6 \mathrm{~g} / \mathrm{hr}$; scaling rates up from the Horizon unit gives a mass of $1.0 \mathrm{~kg}$, and scaling down from the Giner unit gives a mass of $0.6 \mathrm{~kg}$. The larger estimate was used here as a conservative value. The larger vehicle requires an electrolysis rate of $143 \mathrm{~g} / \mathrm{hr}$. Using data supplied by Giner for electrolysis rate and mass for 1,2,5,10, and 12 cell units, a linear curve fit was developed. The rate of $143 \mathrm{~g} / \mathrm{hr}$ would require a 7-cell unit with a mass of approximately $3.4 \mathrm{~kg}$. The power for both commercial electrolyzers was similar at approximately $6 \mathrm{~W}$ per $\mathrm{g} / \mathrm{hr}$ of water electrolyzed.

Pumps. Several water pumps are included in the electrolyzer loop to maintain the flow. PEM electrolyzers typically run with large amounts of excess water to ensure the oxygen and hydrogen gases produced are swept out of 
the cells and to provide cooling for the stack. Assuming a standard cell voltage of 2 volts, the required water flow rate for cooling is approximately 400 times the rate of electrolysis. Because the gases will be stored at high-pressure and because it is easier to increase pressure in a liquid than a gas, it is assumed that the electrolyzer will be operated at a moderately high pressure of 400 psia to ease the later requirement for compression of the oxygen gas. Several pump types and makes were reviewed for relevance. The majority of the very small pumps are not designed for any significant pressure rise. The Micropump GB series was used here as a basis for the mass and power estimates. While advertising the highest pressure-rise capability of all the small pumps reviewed, at 125-psi delta pressure, it still falls short of our desired 400 psi pressure rise. Power for water pumps is a function of flow rate, torque, speed, and pressure rise. For the particular pump considered, the lowest torque shown that will provide the maximum pressure rise of $125 \mathrm{psi}$ is $2400 \mathrm{rpm}$. This will require approximately 20 watts of power to pump $0.62 \mathrm{lpm}$. The water flow rate for the small vehicle is $0.031 \mathrm{lpm}$, which is still one order of magnitude lower. A higher speed of $4000 \mathrm{rpm}$ was considered for the large vehicle. This condition will pump $1.7 \mathrm{lpm}$ while using $54 \mathrm{~W}$.

Recycle Compressor. The recycle compressor in the Sabatier reactor loop must make up for any pressure drop through the reactor, heat exchangers, and methane separation membrane. While a detailed pressure schedule through the system was not calculated here, the very low flow rates should result in minimal pressure drop through each component. For the small vehicle, a Smart Products Air Pump AP-3P04 was used as the basis. This compressor provides a 12-psi pressure rise at a flow rate of approximately $0.4 \mathrm{scfh}$ and $3.25 \mathrm{~W}$. While the mass and power of this pump was used for the plant estimate here, the methane flow rate for the small vehicle is nearly an order of magnitude smaller. For the large vehicle, the Smart Products SP- 8000 was used as a basis. This compressor generates approximately $16 \mathrm{psi}$ pressure rise on $2 \mathrm{scfh}$ at $12 \mathrm{~W}$, which is comparable to the $1.9 \mathrm{scfh}$ required for the large production plant.

Storage Compressors. For storing the oxygen and methane gases, the RIX Industries Rotec and Sabre series compressors were reviewed. Both series provide a maximum outlet pressure of $5945 \mathrm{psig}$, which is significantly greater than the 2000 psia desired in this analysis. Even the smallest of these compressors handles flow rates more than an order of magnitude greater than that needed for the small vehicle, and four times greater than that needed for the large vehicle. Based on conversations with the manufacturer, power levels to operate the Rotec 1 compressor at these small flow rates would be on the order of $11 \mathrm{~W}$. For this assessment, the mass of the existing Rotec 1 compressor was used for both production plants. For power, a conservative value of $20 \mathrm{~W}$ was used for the small plant and $30 \mathrm{~W}$ for the large plant.

Water Production. As noted earlier, a detailed design for water extraction from Martian resources was beyond the scope of this project. Three main paths for water recovery are possible: extracting water from the regolith, extracting water from the permanent or transient ice caps, or extracting water from the atmosphere. Results from the Mars Reconnaissance orbiter and the Mars Phoenix mission, among others, show that a considerable amount of water is accessible in the form of ice in the shallow subsurface regions, particularly in high latitude areas ${ }^{13,14}$. Accessing this water would require a drill or an excavating tool to remove the overburden of regolith, followed by collection and purification by evaporation and condensation of the water. Water could also be recovered from permafrost, which is present everywhere above the latitude bands of $50^{\circ}-60^{\circ},{ }^{15}$ by similar techniques.

However, water production from ice will require a hopper that is restricted to relatively high latitudes. Hydrated minerals are present in some lower latitude locations on Mars, but require higher temperature processing to recover the water content. An alternative resource for water would be to recover water from the atmosphere. Even at the Martian equator, frost was observed to form on the coldest exposed parts of the Mars Exploration Rovers. ${ }^{16}$ Depending on location and season, the amount of water in the atmosphere varies from about five precipitable microns during the driest part of winter to as high as 80 precipitable microns, ${ }^{17}$ corresponding to a water content of about 0.5 to 7 micrograms per liter of atmosphere. This water can be harvested by condensation on a cold finger, or by use of a sorption pump. ${ }^{18}$ It is notable that the sorption pump used here for compression of the carbon dioxide will also efficiently condense the water content of the atmosphere; hence, some water can be harvested simply by collecting, rather than discarding, the water absorbed. High volume collection of water from the Mars atmosphere using sorption would primarily require a blower, in order to increase the amount of atmosphere processed, and a heat exchanger in order to improve the thermal efficiency. Design of such a system is beyond the scope of this project.

\section{Power}

Power will be supplied by a deployable solar array system based on advanced array technology. Values used for specific power are based on an average over the Martian season. ${ }^{19}$ The charging will be faster near perihelion and in the Martian summer, and slower near aphelion in Martian winter. The seasonal variation will be very small for sites at mid-latitudes, but large for landing sites further than approximately 45 degrees from the equator. We assume no 
operation of the production plant during dust storms. It is assumed that dust is shaken off when the arrays are retracted such that the dust losses do not accumulate.

The array is deployed horizontally and is non-tracking, with the orientation of the vehicle assumed to be unknown. Incident solar power is taken as $300 \mathrm{~W} / \mathrm{m}^{2}$ averaged over a 12-hour day, including atmospheric and cosine losses. Incorporating a conservative 10 percent shadow loss from the vehicle, solar cell efficiency of 30 percent, and a 10 percent allowance for dust and other degradation, the solar cells will produce $73 \mathrm{~W} / \mathrm{m}^{2}$ over the 12 -hour day. Reducing this further for an array-packing factor of 85 percent, the array produces $62 \mathrm{~W} / \mathrm{m}^{2}$. For the small production plant at a power of $190 \mathrm{~W}$, this results in a total array area of $3.1 \mathrm{~m}^{2}$. This is about 25 percent smaller than the $4.2 \mathrm{~m}^{2}$ total array area for the two arrays powering the Mars Phoenix lander.

Several values were considered for array specific power on the surface of Mars. Technology that has been flightproven in operation on the surface of Mars, the "Ultraflex" arrays ${ }^{20}$ on the Mars Phoenix lander, provided approximately 22 watts per kilogram under Mars conditions. This array technology would have to be adapted so that it could be retracted after deployment, but it was assumed that this modification could be done with little additional mass. Near-term advances in the technology and materials should be able to improve this to $30 \mathrm{~W} / \mathrm{kg}$. In the farther term, advances in using the lightweight blanket and structures can potentially improve the specific power to approximately $67 \mathrm{~W} / \mathrm{kg}$ at Mars conditions. High specific power arrays are most easily achievable on large area arrays, but the mass improvements will be applicable to smaller area arrays as the structural mass of fixed-mass components is correspondingly reduced.

The small Mars hopper vehicle is envisioned to be a near-term experiment on Mars that will demonstrate the insitu propellant production technology, demonstrate this innovative surface mobility concept, and gather valuable science data at multiple sites. Therefore, the 'near-term' estimate of $30 \mathrm{~W} / \mathrm{kg}$ was used to size the power system for the small hopper plant, resulting in an array mass of $6.4 \mathrm{~kg}(190 \mathrm{~W})$. For nighttime keep-warm power, a $5-\mathrm{W}$ radioisotope heater at $200 \mathrm{~g} / \mathrm{W}$ was assumed. For the balance of the power system, including deployment mechanisms, cabling, controls, and power conversion, a conservative estimate is to double the array mass. ${ }^{21}$ This results in a total power system mass estimate of $12.8 \mathrm{~kg}$.

The large Mars hopper vehicle is envisioned as a second generation hopper, building on the lessons learned from the initial small vehicle and having the capability to investigate multiple sites separated by as much distance as the Curiosity rover's total designed travel. ${ }^{23}$ Due to the mass advantages of scaling to larger array areas, the long-term estimate for solar array specific power of $67 \mathrm{~W} / \mathrm{kg}$ was used to size out the power system. This results in an array mass of $25.4 \mathrm{~kg}(1700 \mathrm{~W})$ for a 30 -day hop, and $12.5 \mathrm{~kg}(840 \mathrm{~W})$ for a 60-day hop. Although the propellant production rate is more than 10 times that for the small plant, many of the components are the same or similar. Therefore, the same 5-W nighttime heater was assumed. For the balance of the power system, we again used a conservative estimate assuming that the balance of system components are equal to the array mass, resulting in a total power system mass of $50.8 \mathrm{~kg}$ and $25 \mathrm{~kg}$ for the 30 - and 60-day hops, respectively.

\section{Mars Hopper}

With mass estimates for the production plant and power system completed, the initial (wet) mass of the Mars hopper vehicle was calculated. For the purposes of estimating propellant tank sizes, linerless composite pressure vessels with an initial storage pressure of 2000 psia were assumed for both the oxygen and methane tanks. With values of $\mathrm{PV} / \mathrm{W}$ conservatively estimated at $1.68 \times 10^{6} \mathrm{~cm}$, these composite tanks offer significant mass savings compared to aluminum tanks. Due to the smallness of the hydrogen molecule, the hydrogen leak rate is a significant factor, and therefore a linerless composite bottle for hydrogen storage was not selected. To mitigate the risk associated with leaking through the composite wall, the hydrogen is stored in a 5000 psia aluminum-lined bottle overwrapped with composite. These aluminum-lined bottles are a significant component of the vehicle's dry mass and may be mass prohibitive as the vehicle size increases.

As discussed above, the hopper was assumed to carry with it enough hydrogen from Earth for 5 hops in three high-pressure tanks. While the genesis for designing an in-situ propelled hopper using a hydrocarbon fuel came from the new belief that water is widely available in the Martian soil, the inclusion of these heavy hydrogen storage tanks will provide a target for the mass of a subsystem to extract the water from the soil (excavator, soil transport in/out, soil dryer, and larger electrolyzer and power). The objective then would be to design a water extraction subsystem that has less mass than the hydrogen storage tanks.

The vehicle's engine design is similar to the one that was tested. A nozzle extension with an expansion ratio of 100 to 1 was designed. The nozzle extension was a heat sink design consisting of Nickel 201 with a wall thickness of $0.635 \mathrm{~cm}$. To extrapolate the engine mass to the large hopper vehicle, data on similar sized pressure fed engines was used to scale engine mass with thrust. Payload for science instruments for the small hopper was set at $5 \mathrm{~kg}$, 
which matches the mass of the instrument suite that is on the MER rovers. Placeholder values for avionics and GN\&C components were used as these were not assessed in detail. Cabling was taken as 1 percent of the dry mass of the vehicle and structure was set at 5 percent of the wet mass. One iteration on cable and structure mass was performed to update these values.

Table XII shows the estimated and calculated masses for the small hopper vehicle. The first column shows the baseline case for a $2 \mathrm{~km}$ hop every 30 days. To calculate the actual propellant required a curve-fit equation was generated from the trajectory data for propellant mass as a function of initial mass for a $2-\mathrm{km}$ hop. Using this equation, the initial wet mass was adjusted, and propellant mass recalculated, until the calculated vehicle wet mass was at or lower than the assumed initial mass used for propellant requirements. As most of the production plant components were already sized down to a minimum mass with excess capacity, the production plant mass was assumed constant during these iterations. The first column in Table XII shows that a $57.9 \mathrm{~kg}$ vehicle should be able to perform the $2-\mathrm{km}$ hop every 30 days. The second column in the table evaluates the vehicle assuming that the hydrogen tank holds only 1-hop's worth of hydrogen to support the production of methane. The difference between this column's vehicle wet mass $(44.8 \mathrm{~kg})$ and the first column is the mass that could be allotted to the water extraction sub-system. Therefore, if the water extraction subsystem could be developed for less than $13.1 \mathrm{~kg}$, then

Table XII. Small Hopper vehicle; 2-km hop.

\begin{tabular}{|l|c|c|}
\hline & Baseline & $\begin{array}{c}\text { No Earth } \\
\text { H2 }\end{array}$ \\
\hline Time between hops, days & 30 & 30 \\
\hline Assumed initial mass, kg & 58 & 58 \\
\hline Mars Hopper Mass Estimates, kg & & \\
\hline Propellant & & \\
\hline Oxygen & 2.46 & 2.46 \\
\hline Methane & 0.72 & 0.72 \\
\hline Hydrogn & 0.72 & 0.00 \\
\hline Tank Mass & & \\
\hline Oxygen & 1.16 & 1.16 \\
\hline Methane & 0.51 & 0.51 \\
\hline Hydrogn & 12.5 & 2.59 \\
\hline Components & & \\
\hline Engine & 4.95 & 4.95 \\
\hline Propellant production plant & 11.1 & 9.40 \\
\hline Payload & 5.0 & 5.0 \\
\hline Solar arrays & 6.4 & 6.4 \\
\hline Power system & 6.4 & 6.4 \\
\hline Radioisotope heat source & 1.00 & 1.00 \\
\hline Avionics & 1.00 & 1.00 \\
\hline GNC & 0.50 & 0.50 \\
\hline Cables & 0.54 & 0.41 \\
\hline Structure & 2.88 & 2.23 \\
\hline \hline Vehicle Initial (Wet) Mass, kg & 57.9 & 44.8 \\
\hline
\end{tabular}

Table XIII. Large Hopper vehicle; 15-km hop.

\begin{tabular}{|l|c|c|c|}
\hline & Baseline & $\begin{array}{c}\text { No Earth } \\
\text { H2 }\end{array}$ & $\begin{array}{c}\text { 60-day } \\
\text { Hop }\end{array}$ \\
\hline Time between hops, days & 30 & 30 & 60 \\
\hline Assumed initial mass, kg & 430 & 430 & 300 \\
\hline Maximum thrust, N & 5363 & 5363 & 3774 \\
\hline Mars Hopper Mass Estimates, kg & \multicolumn{3}{|l|}{} \\
\hline Propellant & & & \\
\hline Oxygen & 43.9 & 43.9 & 30.6 \\
\hline Methane & 12.9 & 12.90 & 9.01 \\
\hline Hydrogn & 12.9 & 0.00 & 9.01 \\
\hline Tank Mass & & & \\
\hline Oxygen & 20.7 & 20.7 & 14.5 \\
\hline Methane & 9.11 & 9.11 & 6.36 \\
\hline Hydrogn & 196 & 39.5 & 139 \\
\hline Components & & & \\
\hline Engine & 22.5 & 22.5 & 16.7 \\
\hline Propellant production plant & 18.8 & 18.8 & 15.6 \\
\hline Payload & 9.98 & 9.98 & 9.98 \\
\hline Solar arrays & 25.4 & 25.4 & 12.5 \\
\hline Power system & 25.4 & 25.4 & 12.5 \\
\hline Radioisotope heat source & 1.00 & 1.00 & 1.00 \\
\hline Avionics & 1.00 & 1.00 & 1.00 \\
\hline GNC & 0.50 & 0.50 & 0.50 \\
\hline Cables & 3.54 & 1.87 & 2.45 \\
\hline Structure & 21.2 & 12.20 & 14.7 \\
\hline \hline Vehicle Initial (Wet) Mass, kg & 426 & 245 & 296 \\
\hline
\end{tabular}

this 2-km hop mission could be performed indefinitely as long as sufficient water is found at the new site.

Table XIII shows the mass estimates for a larger vehicle that can hop $15 \mathrm{~km}$ per hop. The first column shows the baseline estimate for a hop every 30 days. The engine thrust was increased to $5363 \mathrm{~N}$ (1205 lbf) as optimized by the trajectory analysis for minimum propellant usage. The science payload allotment was doubled to provide more science return on the second-generation mission. The solar array specific power was assumed to be $67 \mathrm{~W} / \mathrm{kg}$ from the estimates for 'far term' technology advancements as discussed above. It is clear that the mass of the hydrogen tanks is again a significant portion of the $426 \mathrm{~kg}$ initial wet mass. For comparison, the second column shows the vehicle components with only a single hydrogen tank to hold one-mission's worth of hydrogen extracted from the Martian soil. Comparing the $426 \mathrm{~kg}$ initial mass for Earth-supplied hydrogen to the $245 \mathrm{~kg}$ mass for the single-use hydrogen tank shows that if a soil excavator and water extraction subsystem could be developed for less than $181 \mathrm{~kg}$ of additional mass then the $15-\mathrm{km}$ hop mission could be performed indefinitely.

After the mass of the hydrogen storage tanks, the second largest component mass is the solar arrays and power management system. The third column evaluates a hopper that would travel $15 \mathrm{~km}$ every 60 days, based on the 
assumption that production plant power requirements would be directly related to production rate at this scale. This vehicle also carries with it the large hydrogen storage tanks for a 5-hop mission. By waiting twice as long for each hop, the initial vehicle mass is approximately $300 \mathrm{~kg}$, a reduction of 30 percent.

\section{Conclusion}

The concept of utilizing available resources at the exploration site to provide propellants for the return flight, thereby reducing the total mass launched from Earth, has been discussed since before the first manned lunar landing. More than forty years later this technology concept is still considered enabling for human Mars exploration, yet it has not garnered sufficient funding to fly even the first flight demonstration. The approach set forth in this paper is to combine the use of in situ resources in a new Mars mobility concept that will greatly enhance the science return while providing the first opportunity towards reducing the risk of incorporating ISRU into the critical path for the highly coveted, but currently unaffordable, sample return mission.

The small hopper vehicle evaluated here can travel $2 \mathrm{~km}$ every 30 days with an estimated vehicle mass of $60 \mathrm{~kg}$; this is 65 percent smaller than the 174-kg Mars Exploration Rovers (Spirit and Opportunity) and should be considered as a relatively low-cost Mars science mission that can still travel farther in a 6-month mission than Spirit did in 6 years. The large hopper vehicle evaluated here can travel $15 \mathrm{~km}$ every 30 to 60 days with an estimated vehicle mass of 300 to $430 \mathrm{~kg}$; this is a 50 to 65 percent reduction from the 899-kg Mars Science Laboratory rover (Curiosity) currently on its way to the red planet. ${ }^{22}$ Yet Curiosity's primary mission goal is only $20 \mathrm{~km}$ in 2 years, a distance that can be surpassed by the large hopper vehicle in its second jump.

The analysis presented here showed the feasibility of the concept through analysis of the trajectory and production plant, and demonstration of a low-complexity propulsion system. However, there are several key issues that require more detailed study. As with any planetary exploration, mass and power will be at a premium, and any method that can reduce total mass and power requirements need to be further developed. One such example is the microchannel carbon dioxide sorption pumps operated on a rapid adsorption/desorption cycle that significantly reduces mass while improving thermal efficiency to reduce power for this critical first step in the production plant. However, this new technology needs further development and demonstration in a Mars environment chamber, as do many of the production plant components assumed in this analysis. The ability to find and extract sufficient hydrogen from in-situ water also needs to be evaluated in detail to eliminate the Earth-supplied hydrogen proposed for the first hopper mission. Finally, the concept for a simple ballistic trajectory significantly simplifies the propulsion system and the engine with greatly reduced engine burn times over a continually hovering mode of translation. Several issues still need to be demonstrated, including the ability to control the attitude of the spacecraft and pitch-over during the ballistic coast. However, the potential of this concept to reduce the risk of utilizing in-situ resources in major missions such as sample return and eventually human exploration while simultaneously delivering significant science return has been shown to be feasible and merits continued development.

\section{Acknowledgments}

The authors greatly appreciate support and details from Dr. Robert Wegeng and Dr. Kriston Brooks from Battelle Memorial Institute on the microchannel sorption pump technology. The authors gratefully acknowledge the support of this work by the Glenn Research Center Center Innovation Fund, which is funded by the NASA Office of Chief Technology.

\section{References}

\footnotetext{
${ }^{1}$ National Research Council, Vision and Voyages for Planetary Science in the Decade 2013-2022, National Academy Press, Washington, D.C., 2011.

${ }^{2}$ Landis, G.A., and Linne, D.L., "Mars Rocket Vehicle Using In Situ Propellants," Journal of Spacecraft and Rockets, Vol. 38, No. 5, 2001, pp. $730-735$.

${ }^{3}$ Feldman, W.C., et al., "Global Distribution of Near-Surface Hydrogen on Mars," Journal of Geophysics Research, Vol. 109, E09006, September, 2004, 13 pp.

${ }^{4}$ Smith, P.H., et al., " $\mathrm{H}_{2} \mathrm{O}$ at the Phoenix Landing Site," Science, Vol. 325, No. 5936, 2009, pp. 58-61

${ }^{5}$ OTIS, Optimal Trajectories by Implicit Simulation, Software Package, Ver. 4.0.15, NASA Glenn Research Center, Cleveland, OH 2010.

${ }^{6}$ CEA, NASA-Glenn Chemical Equilibrium Program CEA2, Software Package, NASA Glenn Research Center, May 2004, (www.grc.nasa.gov/WWW/CEAWeb).

${ }^{7}$ Marshall, W.M., Pal, S., Woodward, R.D., and Santoro, R.J., "Benchmark Wall Heat Flux Data for a $\mathrm{GO}_{2} / \mathrm{GH}_{2} \mathrm{Single}$ Element Combustor,” AIAA Paper No. 2005-3572, AIAA Joint Propulsion Conference, July 2005.
} 
${ }^{8}$ Hegde, U., Balasubramamaniam, R., Gokoglu, S., Rogers, K., Reddington, M., and Oryshchyn, L., "Hydrogen Reduction of Lunar Regolith Simulants for Oxygen Production," AIAA Paper No. 2011-608, AIAA Aerospace Sciences Meeting, January, 2011.

${ }^{9}$ Balasubramaniam, R, Gokoglu, S.A., and Hegde, U., "The Reduction of Lunar Regolith by Carbothermal Processing Using Methane," Int. J. of Mineral Processing, Vol. 96, 2010, pp. 54-61.

${ }^{10}$ Linne, D.L., Gokoglu, S., Hegde, U.G., Balasubramaniam, R., and Santiago-Maldonado, E., "Component and System Sensitivity Considerations for Design of a Lunar ISRU Oxygen Production Plant," AIAA Paper No. 2009-1391, AIAA Aerospace Sciences Meeting, January 2009.

${ }^{11}$ Brooks, K.P., Caldwell, D.D., Holladay, J.D., Howard, C.L., Hu, J., Kee, R.J., Lilley, B.P., Rassat, S.D., Romig, K.A., Schlahta, S.N., Simon, T.M., and Zhu, H., "Microchannel In Situ Propellant Production System Project Final Report," Battelle Pacific Northwest Division Rept. PNWD-3670, Richmond, WA, March 2006.

${ }^{12}$ Korablev, O., Moroz, V.I., Petrova, E.V., and Rodin, A.V., "Optical Properties of Dust and the Opacity of the Martian Atmosphere," Advances in Space Research, Vol. 35, Issue 1, 2005, pp. 21-30.

${ }^{13}$ Byrne, S. et al. "Distribution of Mid-Latitude Ground Ice on Mars from New Impact Craters," Science, 329. pp. 1674-1676 (Sept. 2009).

${ }^{14}$ Plaut, J. J., et. al., "Radar Evidence for Ice in Lobate Debris Aprons in the Mid-northern Latitudes of Mars," Geophys Res. Letters, 36. No. 2, L02203, doi:10.1029/2008GL036379, 2009.

${ }^{15}$ Mitrofanov. I. G., et al., "Burial Depth of Water Ice in Mars Permafrost Subsurface," 7th Int. Conf. on Mars, July 9-13 2007, Pasadena CA (abstract 3108).

${ }^{16}$ Landis, G., "Observation of Frost at the Equator of Mars by the Opportunity Rover," 38th Lunar \& Planetary Science Conference (LPSC-XXXVIII), League City TX, Mar 12-16, 2007 (abstract 2423).

${ }^{17}$ Jakoski, B.M. and Haberle, R.M., "The Seasonal Behavior of Water on Mars," Mars, U. Arizona Press, Tucson (1992), pp. 969-1016.

${ }^{18}$ Grover, M.R., and Bruckner, A.P., "Water Vapor Extraction from the Martian Atmosphere by Adsorption in Molecular Sieves," Paper No. AIAA 98-3302, 34th AIAA/ASME/SAE/ASEE Joint Propulsion Conf., Cleveland, OH, July 13-15, 1998.

${ }^{19}$ Haberle, R., McKay, C., Gwynne, O., Atkinson, D., Landis, G., Zurek, R., Pollack, J. and Appelbaum, J., "Atmospheric Effects on the Utility of Solar Power on Mars," Resources of Near Earth Space, U. Arizona Press, Tucson (1993), pp. $799-818$.

${ }^{20}$ Spence, B. R., et. al., "UltraFlex-175 on Sace Technology 8 (ST8) - Validating the Next Generation in Lightweight Solar Arrays," IEEE Aerospace Conference, March 5-12 2005, 5-12, 2005, Big Sky MT.

${ }^{21}$ Landis, G., Bailey, S., and McKissock, B., "Designing Power Systems," Human Spaceflight: Mission Analysis and Design, McGraw-Hill Space Technology Series (1999), pp 643-664.

${ }^{22}$ Mars Science Laboratory Launch Press Kit, November 2011, URL: http://www.nasa.gov/mission_pages/msl/index.html (cited 29 November 2011). 